\title{
Review \\ B Cell Lymphoma 2: A Potential Therapeutic Target for Cancer Therapy
}

\author{
Manzar Alam ${ }^{1}$, Sabeeha Ali ${ }^{1}$, Taj Mohammad ${ }^{1}\left[\right.$, Gulam Mustafa Hasan ${ }^{2}$, Dharmendra Kumar Yadav ${ }^{3, * \mathbb{C}}$ \\ and Md. Imtaiyaz Hassan $1, *$ (D) \\ 1 Centre for Interdisciplinary Research in Basic Sciences, Jamia Millia Islamia, Jamia Nagar, \\ New Delhi 110025, India; manzar987@gmail.com (M.A.); ra.sabeeha@jmi.ac.in (S.A.); \\ taj144796@st.jmi.ac.in (T.M.) \\ 2 Department of Biochemistry, College of Medicine, Prince Sattam Bin Abdulaziz University, \\ Al-Kharj 11942, Saudi Arabia; mgulam@gmail.com \\ 3 Department of Pharmacy and Gachon Institute of Pharmaceutical Science, College of Pharmacy, \\ Gachon University, Hambakmoeiro 191, Yeonsu-gu, Incheon 21924, Korea \\ * Correspondence: dharmendra30oct@gmail.com (D.K.Y.); mihassan@jmi.ac.in (M.I.H.)
}

Citation: Alam, M.; Ali, S.;

Mohammad, T.; Hasan, G.M.; Yadav, D.K.; Hassan, M.I. B Cell Lymphoma 2: A Potential Therapeutic Target for Cancer Therapy. Int. J. Mol. Sci. 2021, 22, 10442. https://doi.org/10.3390/ ijms221910442

Academic Editor: Sarath Chandra Janga

Received: 29 August 2021

Accepted: 23 September 2021

Published: 28 September 2021

Publisher's Note: MDPI stays neutral with regard to jurisdictional claims in published maps and institutional affiliations.

Copyright: (C) 2021 by the authors Licensee MDPI, Basel, Switzerland. This article is an open access article distributed under the terms and conditions of the Creative Commons Attribution (CC BY) license (https:// creativecommons.org/licenses/by/ $4.0 /)$.
Abstract: Defects in the apoptosis mechanism stimulate cancer cell growth and survival. B cell lymphoma 2 (Bcl-2) is an anti-apoptotic molecule that plays a central role in apoptosis. Bcl-2 is the founding constituent of the $\mathrm{Bcl}-2$ protein family of apoptosis controllers, the primary apoptosis regulators linked with cancer. Bcl-2 has been identified as being over-expressed in several cancers. Bcl-2 is induced by protein kinases and several signaling molecules which stimulate cancer development. Identifying the important function played by Bcl-2 in cancer progression and development, and treatment made it a target related to therapy for multiple cancers. Among the various strategies that have been proposed to block Bcl-2, BH3-mimetics have appeared as a novel group of compounds thanks to their favorable effects on many cancers within several clinical settings. Because of the fundamental function of Bcl-2 in the regulation of apoptosis, the Bcl-2 protein is a potent target for the development of novel anti-tumor treatments. Bcl-2 inhibitors have been used against several cancers and provide a pre-clinical platform for testing novel therapeutic drugs. Clinical trials of multiple investigational agents targeting $\mathrm{Bcl}-2$ are ongoing. This review discusses the role of $\mathrm{Bcl}-2$ in cancer development; it could be exploited as a potential target for developing novel therapeutic strategies to combat various types of cancers. We further highlight the therapeutic activity of Bcl-2 inhibitors and their implications for the therapeutic management of cancer.

Keywords: B cell lymphoma 2; cancers; apoptosis; inhibitors; clinical trials; targeted therapy

\section{Introduction}

Bcl-2 is an anti-apoptotic protein that is associated with several cancer progression [1,2]. $\mathrm{Bcl}-2$ was the first protein to be documented among the Bcl-2 family proteins [3]. It was the first gene exhibited to promote prolonged cell survival and growth rather than enhanced proliferation, which revealed that inhibition of cell death is vital in tumorigenesis [4]. $\mathrm{Bcl}-2$ represses apoptosis by inhibiting cytochrome $\mathrm{c}(\mathrm{cyt}-\mathrm{c})$ release from the mitochondria, preventing activation of caspases responsible for apoptosis [5]. Elevated expression of Bcl-2 is involved in many cancer progressions [6]. The increased expression of Bcl-2 is linked with advanced stage neoplasms and poor differentiation [7]. Bcl-2 plays a vital role in angiogenesis and cancer growth [8]. Apoptosis is the most important mechanism of cell death in response to tumor therapies [9]. Targeting the Bcl-2 protein may improve apoptosis by chemotherapeutic agents $[10,11]$. Bcl-2 inhibitors have exhibited promising effects in several malignancies with a single drug and combination with other drugs since $\mathrm{Bcl}-2$ is a potential therapeutic target for malignancies [12].

$\mathrm{Bcl}-2$ is the most significant protein, its overexpression and phosphorylation may be linked to regulation of cell growth, cell cycle, proliferation, DNA repair, and tumorigenesis. 
Elevated expression of Bcl-2 protein has been found in several human cancers [13,14]. $\mathrm{Bcl}-2$ participates in an oncogenic function via survival signaling pathways and its role on the mitochondrial membrane. Several signaling molecules regulate Bcl-2. The phosphorylation of Bcl-2 on Ser70 through growth factor-activated protein kinases triggers the anti-apoptotic function of Bcl-2 [15,16]. p53 regulates Bcl-2 family proteins and hence controls mitochondria-mediated apoptosis [17]. p53 is a controller of the expression of the Bcl-2 gene. It increases $\mathrm{Bcl}-2$ protein expression [18-20]. Overexpression of $\mathrm{Bcl}-2$ showed more activation of signaling molecules in pancreatic cancer cells [21]. Signaling pathways play a major role in controlling the Bcl-2 family of proteins that initiates cell growth/survival via activation of Bcl-2 [22,23].

Here, this review article highlights the present findings on the role of Bcl-2 in the progression of various cancers and its significance as a therapeutic target. We also discussed a comprehensive study of Bcl-2 inhibitors as a therapeutic target for cancer therapy. This investigation summarizes the potential of Bcl-2-inhibitors in the treatment of cancer and novel plans to utilize these inhibitors in pre-clinical and clinical trial applications.

\section{Bcl-2 Family Proteins Mediated Apoptosis}

Apoptosis is the complex and fine-regulated appearance of programmed cell death. It takes part in vital functions such as embryogenesis, immunity, tissue development, and maintenance of homeostasis. Hence, excessive or insufficient cell death may lead to many pathological conditions like cancer $[24,25]$. Apoptosis is an important program of a living cell $[24,26]$. Two pathways initiate apoptosis, the extrinsic pathway and the intrinsic pathway (Figure 1). The extrinsic pathway starts with the activation of particular death receptors and ligand receptors. These ligands contain Apo2L/TRAIL and CD95L/FasL, which bind with DR4/DR5 (TRAIL-R1/R2) and CD95/Fas [27]. The intrinsic pathway of apoptosis is primarily triggered via the Bcl-2 family proteins [28]. Bcl-2 family proteins participate in p53-mediated apoptosis, which interacts with the Bcl-2 family proteins, reduces the mitochondrial membrane permeabilization (MMP), and releases cyt-c that activates caspase-9 [29-32]. The cyt-c and Apaf-1 binding activate pro-caspase-9, forming an "apoptosome" [33]. Both pathways activate caspase-3 and follow the apoptosis pathway (Figure 1) [34].

Bcl-2 family proteins include both pro-apoptotic (Bax, Bak, Bid, Bim, Bad, Bik, Puma, Noxa, etc.) and anti-apoptotic (Bcl-2, Bcl-xL, Bcl-w, Mcl-1, etc.) proteins [35,36]. Bcl-2 family proteins contribute to a common genetic region, the Bcl-2 homology (BH) domain, containing four conserved $\mathrm{BH}$ domains [32,37]. The Bcl-2 family proteins are categorized into anti-apoptotic proteins, pro-apoptotic multi-domain Bcl-2 proteins, and BH3-only proteins. The anti-apoptotic compose BH1-4 [38], while Bax and Bak compose BH1-3 and so-called 'multi-domain' pro-apoptotic proteins [38]. Bcl-2 family proteins were demonstrated to contribute to cancer progression [39,40]. All anti-apoptotic Bcl-2 proteins seem to play the role of oncoproteins, and pro-apoptotic proteins may have a role as tumor suppressors. These molecules perform important functions in cancer progression [41,42]. Further, the $\mathrm{BH} 3$ domain combines with the anti-apoptotic proteins, neutralizing them and initiating apoptosis [43]. The down-expression of pro-apoptotic proteins is linked with cancer progression [44]. Pro-apoptotic Bax was associated with oral cancer progression and drug resistance [45]. Anti-apoptotic Bcl-2 proteins play a major role in the progression of various neoplasms [46] and fuel rapid cell cycle regulation [47], angiogenesis, and regulation of gene expression [48]. Overexpression of anti-apoptotic proteins may drive carcinogenesis $[49,50]$. Anti-apoptotic Bcl-xL was involved in oral cancer progression as well as cisplatin resistance [51]. 


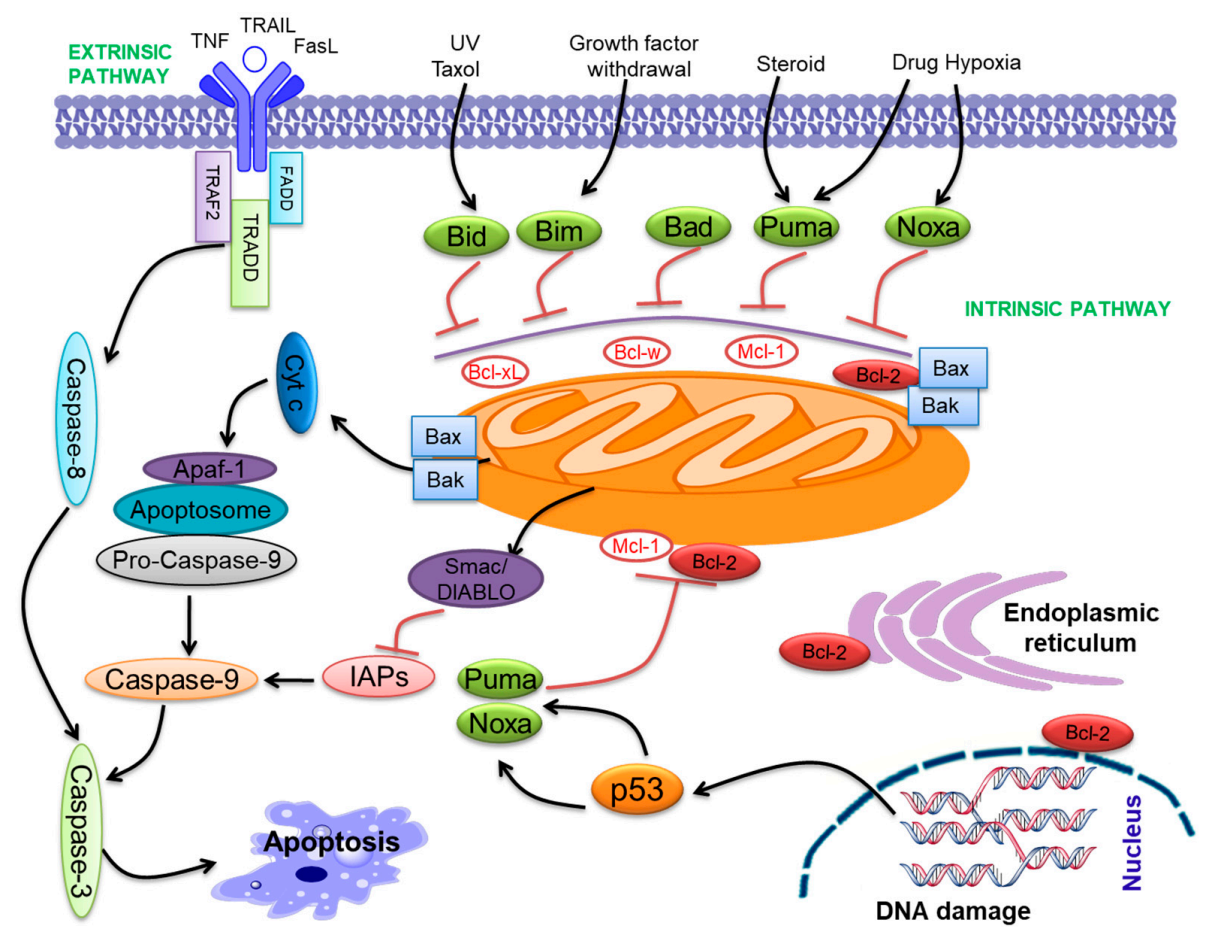

Figure 1. The intrinsic and extrinsic pathways of apoptosis. The two pathways that initiate apoptosis are the extrinsic (or death receptor initiated by ligand binding and subsequent activation of caspase-8) pathway and intrinsic pathway (driven by Bcl-2 family proteins, release cyt-c and activation of caspase-9) of apoptosis. Both pathways lead to a common apoptosis pathway by activating caspases$3,-6$, and -7 , triggering apoptosis. Bcl-2 family proteins are primarily localized to mitochondria and present on the ER and the perinuclear membrane in hematopoietic cells.

\section{Discovery of Bcl-2}

The oncogenic perspective on Bcl-2 was primarily proposed in 1988 by Reed et al. utilizing gene transfer technology [52]. Bcl-2 gene rearrangements were explained to be linked with reduced prognosis in large-cell non-Hodgkin's lymphomas (NHL) [53]. The study of chromosomal rearrangements, which occur in human cancers, has been the most potent and exciting approach for analyzing the molecular systems that trigger tumor cell growth. The examination of the $t(14: 18)$ translocation breakpoint and the finding of the $B c l-2$ gene had a unique impact on our thoughts on fundamental cell biology in malignant and normal cells [54-56]. Moreover, $t(14: 18)$ chromosomal translocations were observed via PCR in several normal individuals $[57,58]$. The Bcl-2 proto-oncogene was initially cloned from the $t(14 ; 18)$ translocation breakpoint in human follicular B cell lymphoma [3]. It is encoded by the $B c l-2$ gene in the case of the human genome, and it is specified as an oncogene [56]. It was identified due to its involvement in $t(14 ; 18)$ chromosomal translocations examined in non-Hodgkin's lymphomas [56]. In translocations $t(14 ; 18)$, the $B c l-2$ gene is present on chromosome 18, which becomes combined with the immunoglobulin heavy-chain $(\operatorname{IgH})$ locus present at chromosome 14 .

Effects in transcriptional activation of $\mathrm{Bcl}-2$ gene and the over-production of its protein occur in B-cells. Hence, Bcl-2 was expected to present another growth-inducing oncogene while it appeared to start the translocation breakpoint sequence. Bcl-2 was established to increase cell growth and obstruct cell death [3,59]. A study of experimental retrovirusinduced Bcl-2 overexpression in the mouse bone marrow cells showed that Bcl-2 overexpression alone could not be sufficient for tumorigenesis [3,59]. Increased Bcl-2 protein expression can certify the perseverance of a cell clone through the more active $B c l-2$ gene, awaiting promotion of tumorigenic alterations or mutations appearing in the result. The introduction of the cDNA of Bcl-2 in IL-3-dependent lymphoid and myeloid cells endorsed cell growth in the absence of the cytokine by the cells being sustained in a G0 position [3,59]. 
Experiments among transgenic mice, which overproduced Bcl-2 in B-cells, have powerfully confirmed the theory that inhibition of apoptosis characterizes one of the crucial steps in the process of tumorigenesis credibly $[60,61]$. The results achieved with mouse models are similar to the detected impact of the expression of Bcl-2 in cancers. Chromosomal Bcl-2 translocations affecting overexpression of protein are observed in follicular center B-cell lymphoma and CLL. These cancers are benign and consist of primarily quiet, non-cycling cancer cells $[62,63]$.

\section{Bcl-2 Structure and Function}

Bcl-2 is a $26 \mathrm{kDa}$ protein that is present on the mitochondrial outer membrane. However, it is also found on the ER membrane and the nuclear envelope [22], where it plays a pivotal role in promoting cellular growth, survival, and apoptosis. The $B c l-2$ gene encodes Bcl-2 in the human genome, specified as an oncogene [56]. It is $\sim 250 \mathrm{~kb}$ in length and comprises three exons and two promoters [3]. This gene activates by the chromosomal translocation mechanism in various human cancers $[64,65]$. Bcl-2 was the first protein to be identified among Bcl-2 family proteins. Bcl-2 has two isoforms, Bcl-2 $\alpha$ as well as Bcl-2 $\beta$; Bcl-2 $\alpha$ is anti-apoptotic [66].

$\mathrm{Bcl}-2$ is triggered by many transcription factors, including p53 [67], AP1, NF- $\mathrm{kB}$, NFAT, and CRE [68]. Two promoter regions were documented in the $5^{\prime}$-untranslated region ( $5^{\prime}$-UTR) of the $\mathrm{Bcl}-2$ gene (Figure 2A). Moreover, the first promoter is situated 1386 to $1423 \mathrm{bp}$ upstream of the translation starting site. It is the main transcriptional promoter [69,70], while the second promoter is situated $1.3 \mathrm{~kb}$ downstream from the first promoter near the first exon $[69,70]$. Regulations of Bcl-2 through NFKB, as well as AP-1, are vital in oral cancer and chemoresistance [71]. The major breakpoint region (MBR) in the $3^{\prime}$-UTR of the $B c l-2$ gene is about $200 \mathrm{~kb}$ downstream of the promoter that is a transcriptional regulatory element, which induces $B c l-2$ gene activity [72]. The regulatory role of the MBR is very much related to special AT-rich sequence binding protein 1 (SATB1) [48]. The 279-bp MBR in the $3^{\prime}$-UTR of the $B c l-2$ gene is a binding site of the SATB1, which is well identified as involving gene regulation [73]. The upstream region (21603 to 21579) of the promoter of the $\mathrm{Bcl}-2$ gene is composed of two GC/GA rich sites on 21601 (5'-GGGCTGG-3') as well as 21588 ( $3^{\prime}$-GGAGGG-5'), which bid Sp1 protein [74]. The Bcl-2 gene contains three exons; exon 1 and exon 2 encode the four BH domains, while exon 3 encodes the TM domain, which attaches the protein to intracellular membranes (Figure 2B) $[69,75]$.

$\mathrm{Bcl}-2$ protein contributes to the $\mathrm{BH}$ domain's common genetic region and contains four conserved $\mathrm{BH}$ domains [32,37]. Bcl-2 is a $26 \mathrm{kDa}, 239$ amino-acid protein that composes four domains, $\mathrm{BH} 1, \mathrm{BH} 2, \mathrm{BH} 3$, and $\mathrm{BH} 4[38,76]$. The $\mathrm{BH} 4$ domain residues (10-30), BH3 domain residues (93-107), BH1 domain residues (136-155), and BH2 domain residues (187-202) [76] (https:/ / www.uniprot.org/uniprot/P10415\#structure; accessed on 15 August 2021) (Figure 3A) and the amino acid sequences of the BH1-4 domains of Bcl-2 [76] (Figure 3B) are provided. The structure of a Bcl-2 chimeric protein comprising a truncated loop obtained from Bcl-xL among the $\mathrm{H} \alpha 1$ as well as $\mathrm{H} \alpha 2$ was initially observed through NMR spectroscopy [77]. Bcl-2 shows a tertiary structure (Figure 3C) containing two hydrophobic $\alpha$-helices ( $\mathrm{H} \alpha 5$ as well as $\mathrm{H} \alpha 6)$ enclosed via amphipathic $\alpha$-helices [77], since from $\mathrm{N}$-terminus to $\mathrm{C}$-terminus the $\mathrm{H} \alpha 1$ to $\mathrm{H} \alpha 8$ are attached one by one with/without a loop. However, the BH4 domain is well conserved at the N-terminal domain of Bcl-2, containing a length of 20 amino acids (10-30, residues) arranged in an $\alpha$-helical construction. Therefore, $\mathrm{BH} 1, \mathrm{BH} 2$, and $\mathrm{BH} 3$ domains make a hydrophobic groove where $\mathrm{BH} 3-$ only proteins may bind since mutations in this area were observed to stop the anti-apoptotic role of Bcl-2; the deletion of the Bcl-2-BH4 domain causes loss of the ability to bind BH3-only proteins $[78,79]$. $\mathrm{Bcl}-2$ attaches to $\mathrm{Bax}$ by its $\mathrm{BH} 1$ and $\mathrm{BH} 2$ domains; this interface is vital to its function in regulating apoptosis, as shown in cells responding to cellular stress [5]. Bcl-2 is up-regulated and able to bind with Bax, which reduces apoptosis [66]. Bcl-2 BH1-2 domains are required for the inhibition of apoptosis [5]. The Bcl-2 protein binds and suppresses NALP1, decreasing caspase activation and interleukin-1beta (IL-1beta) production. 
The loop between BH4 and BH3 is needed for interaction with NLRP1 [80]. Bcl-2 was established to target Raf-1/ MAPK/ ERK for mitochondria in cells. Targeting the dynamic Raf- 1 for the mitochondria can induce resistance for staurosporine-mediated cell death by interface with Bcl-2 [81]. Bcl-2 BH4 domain may attach directly to c-Myc, which promotes genetic instability, DNA damage, and tumorigenesis; hence, Bcl-2 is crucial to increased c-Myc transcriptional action and repression of DNA repair [82].

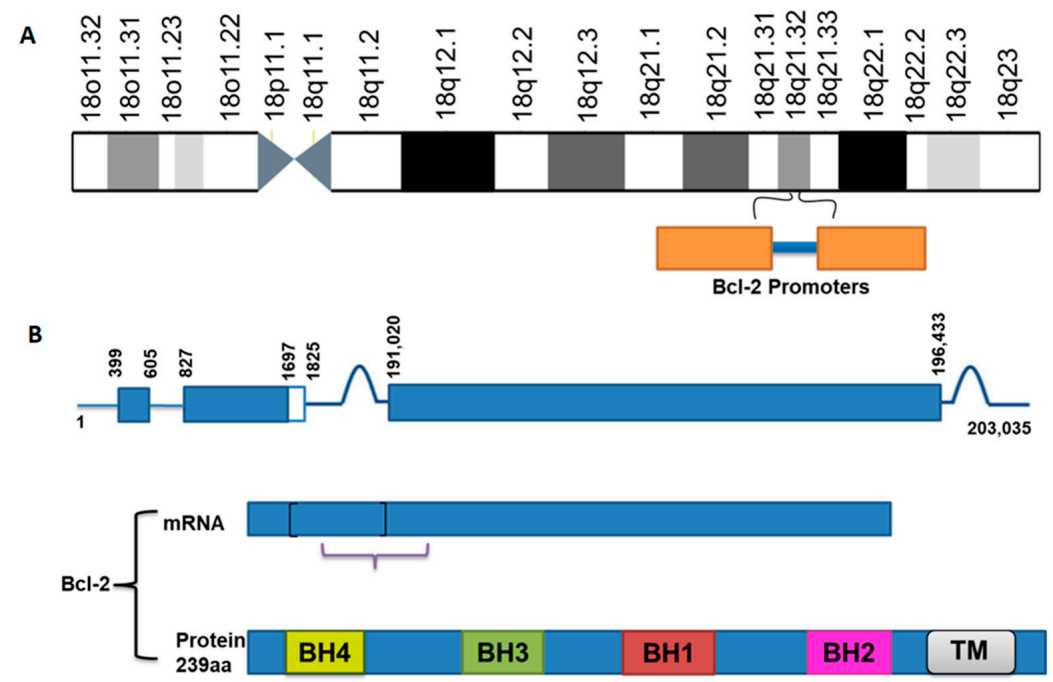

Figure 2. Structural composition of Bcl-2.(A) Figure indicating the position of the Bcl-2 gene and promoters in the human chromosome. (B) The figure shows the $\mathrm{Bcl}-2$ gene composed of three exons, exon 1 and exon 2 encoding the four $\mathrm{BH}(\mathrm{BH} 1-4)$ domains and exon 3 encoding the transmembrane (TM) domain.

A

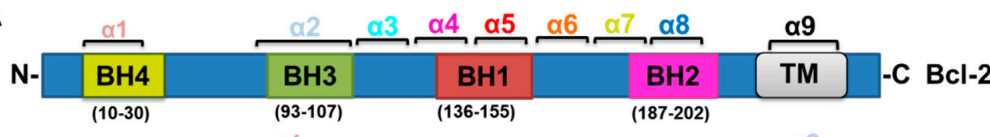

B MAHAGRTGYDNREIVMKYIHYKLSQRGYEWDAGDDVEENRTEAPEGTESEVVHLA

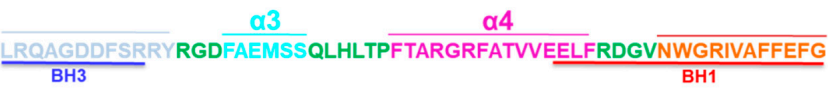

$\frac{a 5}{\text { GVMCVESVNREMSPLVDNIALWMTEYLNRHLHTWIQDNGGWDAFVELYGPSMR }} \frac{a 6}{\text { BH2 }}$

C
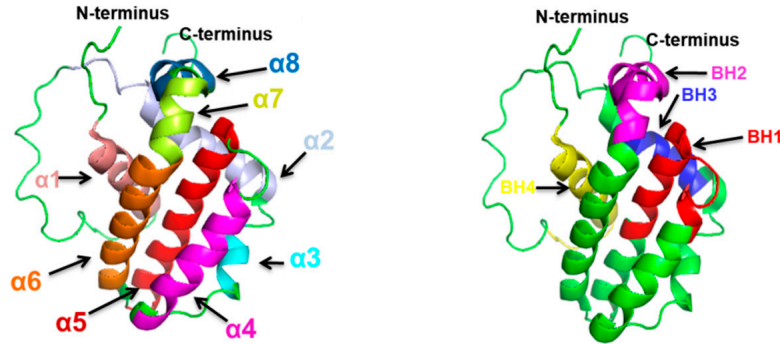

Figure 3. Bcl-2 amino-acid sequences and three-dimensional structure. (A) Bcl-2 is a $26 \mathrm{kDa}$, 239 amino-acid protein that is composed of four domains, the BH4 domain (residues 10-30), BH3 domain (residues 93-107), BH1 domain (residues 136-155), and BH2 domain (residues 187-202). (B) The amino acid sequences of the BH1-4 domains of Bcl-2. The colored letters denote various $\alpha$-helices $\alpha 1-\alpha 8(\mathrm{H} \alpha 1-\mathrm{H} \alpha 8)$ and BH1-4 domains of Bcl-2. (C) The tertiary structure of Bcl-2; highlighted regions denote $\alpha$-helices $(\alpha 1-\alpha 8)$ and BH1-4 domains. The left panel indicates the Bcl-2 tertiary structure with $\alpha 1-\alpha 8$ with various colors, showing the same color coding as (B) (PDB ID: $1 \mathrm{G} 5 \mathrm{M})$. The right panel indicates the structure of Bcl-2 with the BH1-4 domains. 


\section{Bcl-2 Mediated Cancer Development}

Bcl-2 plays a pivotal role in promoting cellular growth and survival that blocks proapoptotic Bcl-2 family proteins, which inhibit apoptosis [83]. Over-expression of the Bcl-2 gene is involved in cancer development [1,2]. Bcl-2 represses apoptosis by blocking the release of cyt-c from the mitochondria, inhibiting the activation of caspases responsible for apoptosis [5]. The increased expression of Bcl-2 is linked with advanced-stage neoplasms and poor differentiation [7]. Elevated expression of Bcl-2 is involved in various cancer progression [6]. The increased regulation of Bcl-2 protects drug-induced cells from apoptosis [84]. Upregulation may happen via several mechanisms, including gene amplification, chromosomal translocation, gene/ protein expression and more. These mechanisms are involved in the regulation of $\mathrm{Bcl}-2$ mediated cancer progression [85]. Paclitaxel may reverse resistance for cisplatin, initiating phosphorylation of Bcl-2, which facilitates cell death. Bcl-2 plays a vital role in angiogenesis as well as cancer growth [8]. Bcl-2 blocks TRAIL-induced cell death in glioblastoma, neuroblastoma, and breast carcinoma cells [86].

In the apoptotic pathway, inactive p53 fails to promote cell death through the interference disruption of MMP, disrupting the Bcl-2/Bax ratio [87]. p53 is a controller of the expression of the $B c l-2$ gene. It increases Bcl-2 protein expression [18-20]. The loss of normal p53 function results in diminished Bax expression [20]. Bcl-2 is the essential molecule whose phosphorylation and high expression involve controlling cell survival, proliferation, DNA repair, cell cycle, and tumorigenesis. Bcl-2 has been associated with several human cancers $[13,14]$. Upregulation of Bcl-2 protein certifies which over-proliferating cells grow when acquiring mutations or inducing tumorigenesis [88]. Endogenous Bcl-2 expressed in many cells may be phosphorylated on various sites in the flexible loop domain (FLD) such as Thr69, Ser70, and Ser87, which is linked with regulation of cell death [89]. Bcl-2 phosphorylation on Ser70 through growth factor-activated protein kinases, including PKC, may positively trigger the anti-apoptotic role of Bcl-2 [15,16]. The capability of Bcl-2 to balance the action of healthy characterized oncoproteins such as Myc underlies an extremely pivotal theory in cancer biology [90]. First, oncogenic mutations in genes resulting in out of control cell survival certainly activate safety machinery, which causes the removal of the mutated cells [91].

\section{Targeting of Bcl-2 as a Novel Anticancer Treatment}

As we previously described in the earlier sections, dysregulated Bcl-2 family protein expression initiates the oncogenic transformation of healthy cells. Multiple Bcl-2 family proteins, Bcl-2 and Bax, are frequently established as over-or underexpressed in cancer tissue. The neoplastic cells can remain resistant to several apoptotic cues, which generates vital prerequisites to grow those eventual manifestations of tumors recognized as metastasis. Presently, anti-tumor protocols exploited in the clinic like radio- and chemotherapy aim to remove quickly proliferating cancer cells through "encouraging" completion of their mitochondrial apoptotic pathway. Overexpression of Bcl-2 via the reduction of Bax expression has been associated with the acquired resistance of cancers to radiation and chemotherapy. Hence, functional obstruction of anti-apoptotic Bcl-2 proteins or overexpression of pro-apoptotic $\mathrm{Bcl}-2$ proteins might restore apoptosis in cancer cells and sensitize these cancers for chemotherapies and radiotherapies.

Due to the prominent function of $\mathrm{Bcl}-2$ in inhibiting apoptosis, it has been identified as a potential target for the development of novel anti-tumor therapeutics. The improvement of novel anticancer therapies targeting Bcl-2 protein and Bcl-2 family proteins is an aim followed via several research groups, and their job entails three key strategies: (i) Decreasing regulation and expression of the anti-apoptotic Bcl-2 family proteins by targeting their mRNAs; (ii) Interference with the role of anti-apoptotic Bcl-2 family proteins on the protein stage by utilizing Bcl-2-attaching compounds; (iii) Induction of cell death via the introduction of pro-apoptotic proteins. The first aim, particularly targeting Bcl-2 family proteins, is based on the reality that antisense oligonucleotides can hybridize for target mRNAs, leading to their degradation after reducing de novo synthesis of Bcl-2 protein. 
Based on the high homology of some Bcl-2 and Bcl-xL mRNA regions, it was tried to plan antisense oligonucleotides by double specificity, targeting the two main anti-apoptotic proteins engaged in tumorigenesis. Pre-clinical study of antisense oligonucleotides indicated concurrent downregulation of $\mathrm{Bcl}-2$ and $\mathrm{Bcl}-\mathrm{xL}$ and cell death induction in several cancers in vitro and in vivo [92-94].

To hinder the role of Bcl-2 in the protein stage, Wang et al. [95] proposed other approaches where small molecules attach and inactivate the overexpressed Bcl-2 protein. As a scientific study showed, a cell porous Bcl-2 attaching peptide was planned through chemically binding a fatty acid for a peptide obtained from Bax, which blocked survival of Bcl-2 transfected HL-60 cell lines during in vitro and in vivo studies. Small-molecule inhibitors were documented which attach to $\mathrm{Bcl}-2$ and $\mathrm{Bcl}-\mathrm{xL}$, interrupting the interface between $\mathrm{Bcl}-2 / \mathrm{Bcl}-\mathrm{xL}$ and the $\mathrm{BH} 3$ domain, thereby inducing apoptosis $[96,97]$. Hence, the cell's decision to go through cell death depends, among other things, on the percentage of pro-apoptotic and anti-apoptotic Bcl-2 proteins; through increased regulation of proapoptotic proteins, this has been attempted for apoptosis induction in cancer cells. Thus, Bax expression in LNCaP affected an $85 \%$ decrease in cell viability by induction of cell death, showing the potency of a similar strategy [98]. The therapeutic function of peptides tolerates many problems; hence small agents mimicking particular $\mathrm{BH} 3$ domains could make excellent tools for clinical trials. More current approaches for targeting Bcl-2 include exploiting inhibitors that mimic $\mathrm{BH} 3$ composing proteins and attach particularly in the hydrophobic groove at the anti-apoptotic proteins since these small molecules are also known as BH3-mimetics.

\section{Bcl-2 Inhibitors}

We summarize here the critical Bcl-2 inhibitors from published patents and literature (Table 1). Bcl-2 inhibitors may inhibit cancer cell growth and survival (Figure 4). These inhibitors were reported in the patents as well as literature databases.

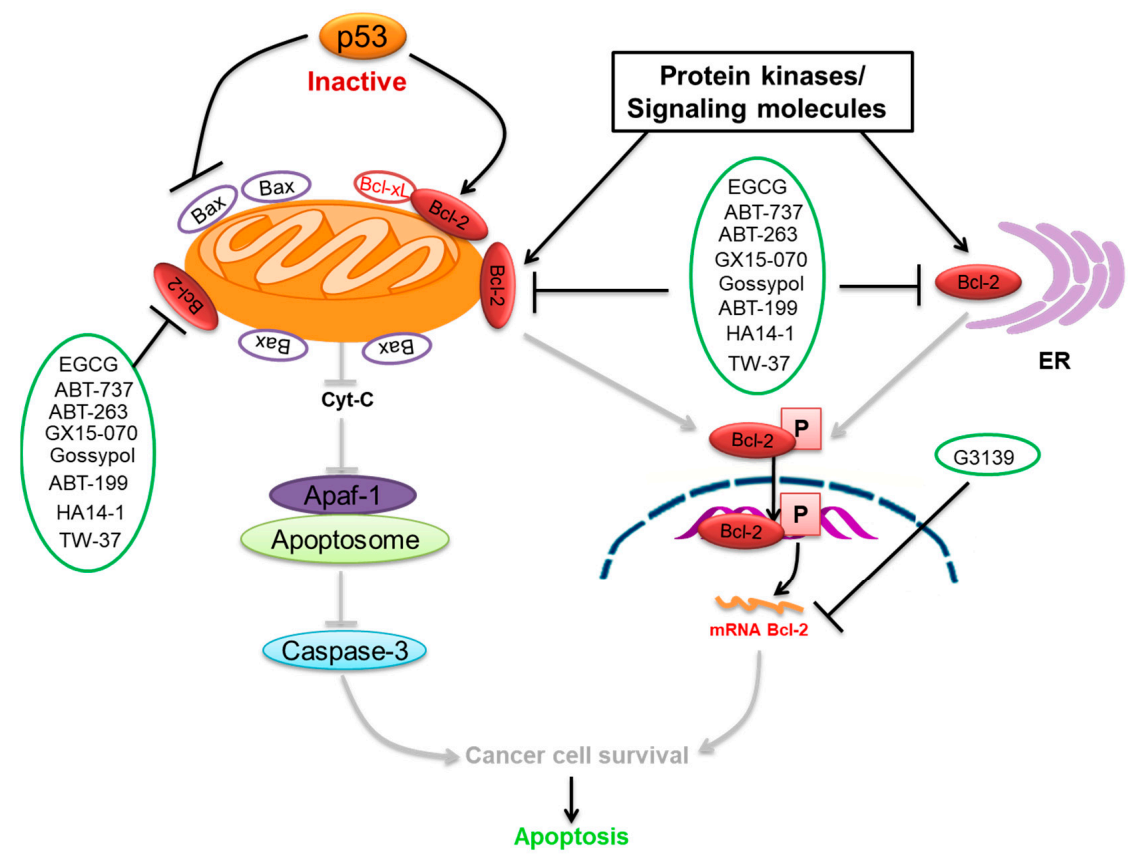

Figure 4. Bcl-2-mediated apoptosis cascade and the mechanism of action of inhibitors. Overexpression of Bcl-2 might be blocked and inhibited through Bcl-2 inhibitors. Inhibitors block cancer progression by targeting signaling molecules or protein kinases that abrogate Bcl-2 expression and decrease the expression of $\mathrm{Bcl}-2$ by inhibiting cell growth and proliferation and initiating apoptosis. 
Table 1. Bcl-2 inhibitors are used for the therapeutic targeting of several cancers.

\begin{tabular}{|c|c|c|c|c|c|c|}
\hline Agents & Chemical Structure & $\mathrm{IC}_{50}$ for Bcl-2 $(\mu \mathrm{M})$ & $\begin{array}{l}\mathrm{IC}_{50} \text { for Bcl-xL } \\
(\mu \mathrm{M})\end{array}$ & Used for Treatment & Clinical Status & References \\
\hline G3139 & & NA & NA & $\begin{array}{l}\text { Solid Tumor (ST), } \\
\text { SCLC, Melanoma } \\
\text { Leukemia, etc. }\end{array}$ & Phase 1 & {$[99,100]$} \\
\hline EGCG & & 0.45 & 0.59 & $\begin{array}{l}\text { HNSCC, OSCC, } \\
\text { other cancers }\end{array}$ & Phase $1 / 2$ & [101-103] \\
\hline ABT-737 & & 0.12 & 0.064 & $\begin{array}{l}\text { HNSCC, ST, PC, } \\
\text { Leukemia, etc. }\end{array}$ & Phase $1 / 2$ & {$[101,104,105]$} \\
\hline ABT-263 & & NA & NA & $\begin{array}{l}\text { ST, Haemato } \\
\text { logical malig- } \\
\text { nancies, SCLC }\end{array}$ & Phase $1 / 2$ & {$[106,107]$} \\
\hline ABT-199 & & 0.1 & NA & ST, Breast cancer & $\begin{array}{l}\text { Approved for use } \\
\text { in CLL }\end{array}$ & {$[108,109]$} \\
\hline TW-37 & & NA & NA & $\begin{array}{l}\text { HNSCC, Prostrate } \\
\text { Cancer, PC, }\end{array}$ & Phase $1 / 2$ & {$[110,111]$} \\
\hline Gossypol & & $0.28-10$ & $0.4-3.03$ & HNSCC, ST, PC & Phase $1 / 2$ & {$[101,112]$} \\
\hline $\begin{array}{l}\text { GX15-070 } \\
\text { (Obatoclax) }\end{array}$ & & NA & NA & $\begin{array}{l}\text { HNSCC, PC, ST, } \\
\text { NSCLCC }\end{array}$ & Phase 1 & {$[113,114]$} \\
\hline HA14-1 & & $\sim 9$ & NA & $\begin{array}{l}\text { HNSCC, leukemia, } \\
\text { lymphoma, colon } \\
\text { cancer, etc. }\end{array}$ & Pre-clinical & {$[113,115,116]$} \\
\hline Chelerythrine & & $\sim 10$ & $\sim 10$ & HNSCC, ST, etc. & & {$[101,117]$} \\
\hline S55746 & & NA & NA & $\begin{array}{c}\text { Hematological } \\
\text { tumor }\end{array}$ & Phase 1 & [118] \\
\hline
\end{tabular}




\subsection{Oblimersen}

Oblimersen (G3139) is a phosphorothioate Bcl-2 antisense oligodeoxynucleotide, which targets the mRNA of Bcl-2. The apoptosis mechanism of Bcl-2 antisense may be grouped into two types, apoptotic and nonapoptotic, based on their apoptotic ability. G3139 antisense increases Bax and PARP, which releases cyt-c for activating caspases and releases Smac/DIABLO for antagonizing inhibitors of cell death proteins from mitochondria for stimulating DNA fragmentation [119]. Inhibitors activate caspase-3 as well as caspase-9 that initiates cell death. Bcl-2/Bcl-xL interacts with the BH3 domain of Beclin-1, where pharmacological disturbance of the interaction between Beclin-1 and Bcl-2 may induce autophagy [120]. Bcl-2 decreased regulation through Bcl-2 antisense and was identified to stimulate autophagic cell death within HL-60 cells, possibly by releasing Beclin-1 [121]. Oblimersen was clinically studied in combination with other anti-tumor chemotherapeutic drugs in multiple cancers $[99,100]$. Oblimersen has studied in current phase II as well as phase III clinical trials. Oblimersen was designed to target Bcl-2 as well as Bcl-xL. Some compounds have indicated attractive clinical study in phase I and II trials, particularly when combined with other cytotoxic drugs [122,123]. Anti-Mcl-1 AON reduced cell viability in vitro in combination with bortezomib and chemotherapy [124].

\subsection{Gossypol}

Gossypol (AT-101), a natural compound, was extracted in 1915 from cottonseed [125]. It has been widely documented since the 1980s, like contraceptives and anti-tumor drugs [126,127]. Gossypol has anti-tumor activity because of extensive results on cells, which trigger Bcl-2 protein and caspases [128], DNA damaging capability, and trigger p53 [129]. It was initially exploited to examine glial cancers; however, its mechanism of action was unidentified at that time [130]. Gossypol occurs inside the racemic shape, and Levo isoform is presently in clinical trials [131]. Levo isoform was indicated to be highly effective in its survival inhibitory results. Multi-dimensional NMR techniques have observed Levo isoform binding with the hydrophobic groove of Bcl-xL and Bcl-2 [132], which generates ROS and cytochrome $c$ release [133]. Gossypol is presently in pre-clinical study. AT-101 shows submicromolar attaching affinity to Bcl-2 as well as Mcl-1. However, gastrointestinal toxicity has been dose preventive in Phase I and II clinical studies for prostate cancer. Apogossypol is in pre-clinical improvement. Apogossypol looks for superior targets on Bcl-2 and Mcl-1 that can reduce the systemic toxicities detected with gossypol.

\subsection{Obatoclax}

Obatoclax (GX15-070) is an indole bipyrrole complex, which antagonizes Bcl-2, Mcl-1, Bcl-xL and Bcl-W [134]. Obatoclax was proposed after researchers discovered Bcl-2 proteins, which have promise for conformational alterations; they utilized high throughput screening of natural amalgam libraries, disturbing protein-protein interactions [135]. It can block the direct interface among Mcl-1 and Bak that was observed to overcome the resistance for ABT-737 and bortezomib [136]. Obatoclax may regulate cell death in NSCLC and might increase cisplatin-based therapy-mediated death [137]. In a pre-clinical trial, it was indicated for stimulating promising cytotoxic reactions against cancer cells and increasing the antimyeloma action induced through bortezomib [138]. Obatoclax was observed for stimulating Bax-mediated cell death in cholangiocarcinoma [132]. Hence, this compound has indicated activity against several tumor cells, including melanoma, esophageal cancer cells, and PC cells [114,115]. Obatoclax increased TRAIL-induced apoptosis, as observed via the Annexin $V$ group accompanied by activation of caspase- $8,-9$, and -3 , and cleavage of Bid. Hence, it potentiated TRAIL-induced Bak/Bax activation, releasing cyt c, Smac, and AIF. These mechanisms were primarily the apoptotic result of obatoclax, including, dislocation of Bak from its confiscation via Bcl-xL/Mcl-1 that liberates Bim from Bcl-2 [139]. Pre-clinical trials indicated that obatoclax has single-drug activity and increased in vitro cytotoxicity of bortezomib against several myelomas [136]. 


\subsection{EGCG}

Epigallocatechin-3-gallate (EGCG) is the most abundant and closely examined polyphenol in green tea $[140,141]$. The chemotherapeutic effects of EGCG have been documented against various cancers [142-144]. EGCG alters and inhibits the Bcl-2 family protein ratio and activates caspases in cancer cells [145-147]. It has anticancer effects that increase Bax and Bak and decrease Bcl-xL and Bcl-2, initiating activation of caspases-9 and inducing cell death in SCC cancer cells [148,149]. EGCG leads to down-regulation of Bcl-2 and Bcl-xL [150]. The interaction of EGCG with p53 disrupts p53 with its regulatory E3 ligase MDM2. It reduces the ubiquitination of p53 through MDM2, since EGCG interrupts the binding of p53 for its regulator MDM2, stabilizing p53 through blocking p53 ubiquitination as well as degradation [151]. EGCG was documented from a library of some 2295 phytochemicals as an inhibitor of p53 with MDM2 interaction [152].

\subsection{HA14-1}

HA14-1 is an inhibitor of anti-apoptotic proteins, which was documented via structurebased screening [115]. HA14-1 stimulated cell death in several tumor cells [153]. It increased the cytotoxicity of doxorubicin, TRAIL ligand, bortezomib, and flavopiridol, resulting in a growth stoppage in the glioblastoma xenograft model [153]. The attaching affinity of HA14-1 for Bcl-2 is comparatively elevated compared to inhibitors of anti-apoptotic Bcl-2 proteins [115]. HA14-1 decomposes quickly within the solution, while a chemical alteration has developed its constancy [154]. The HA14-1 ligand of the Bcl-2 protein surface pocket was proposed [155]. This molecule has exposed the activity of several tumor cell lines [156,157]. HA14- 1 is unbalanced on physiological conditions. However, it crumbles quickly and produces ROS, which might be a mediator of apoptosis, and this compound must be utilized carefully like a qualified opponent against anti-apoptotic proteins [158].

\section{6. $A B T-737$}

ABT-737 is a potent inhibitor of Bcl-2 and Bcl-xL [159], and its application in cancer therapeutics has been observed [104]. ABT-737 has its effect on activating caspase-3, leading to cell death. ABT-737 up-regulates pro-apoptotic Noxa expression via synergistic combination with chemotherapy [104]. ABT-737 binds with a very high affinity to $\mathrm{Bcl}-\mathrm{xL} / \mathrm{Bcl}-2$ because of their similar structure [105]. Hence, Bcl-2 is inhibited due to the binding of ABT-737 in its hydrophobic groove, which relocates any bound pro-apoptotic BH3-containing proteins [105]. ABT-737 stimulated the caspase-3 activation as well as cleavage of PARP, which induced cell death. ABT-737 decreased the activation of Akt expression, which is involved in this signaling pathway in the inhibition of gastric cancer cell growth. p53 was observed to be linked to the effect of ABT-737 as well as naringenin in gastric cells [160]. Data showed ABT-737 and epothilone B caused a blockade of the signaling pathways that could synergistically stimulate apoptosis and anti-proliferation in human cancer cells [161].

\subsection{ABT-263}

ABT-263 (Navitoclax) shares analogous biological characteristics with ABT-737. It acts as a single drug in SCLC xenografts; it increased the activity of other therapy drugs in preclinical trials of B-cell lymphoma and multiple myeloma [107]. It is in a clinical study for chronic myelogenous leukemia as well as SCLC in adults. ABT-263 is orally bio-available and attaches to Bcl-2, Bcl-xL, as well as BCL-w [107]. The biological action of ABT-737 and ABT-263 is shown to be similar; ABT-263 was observed to be more highly sequestered via human serum albumin than ABT-737 [162]. ABT-263 has been in clinical trials for lymphoid malignancies and solid tumors. However, while the effects in hematological cancers were promoted and single-drug activity was identified [106], the efficiency of ABT-263 like a single drug in solid tumors was a little unsatisfactory. In the Phase I doseescalation trial, 47 patients were registered; 27 had SCLC [163]. The pre-clinical data of SCLC patients reacted better than the other cancers. In the phase II trial, patients with SCLC 
were established on a lead-in dose of $150 \mathrm{mg}$ daily for one week pursued via $325 \mathrm{mg}$ of ABT263 daily [164]. Navitoclax-induced cytotoxicity engages the destruction of interactions between Bcl-2/Bcl-L, BIM, and Bax translocation and consequently liberates cytc, activating apoptosis. Hence, this mechanism was detected to be caspase-dependent [107]. It has been assessed frequently in combination with other agents, particularly in solid tumors [105]. In phases I and II, trial studies were performed in patients with refractory CD20+ lymphoid tumors [165].

The main toxicity of ABT-263 was an on-target result of Bcl-xL expressed in platelets [166-168]. The finding that thrombocytopenia was a key mechanism-based result of ABT-263 led to studies that exhibited the significance of Bcl-xL as a molecular clock in platelets [166]. Pharmacological inactivation of Bcl-xL decreases platelet half-life and causes thrombocytopenia in a dose-dependent way [166]. The antagonistic equilibrium between Bcl-xL and Bak comprises a molecular clock, which decides platelet life span; this shows an essential paradigm of cellular homeostasis that has profound suggestions for the diagnosis and treatment of disorders that affect platelet number as function [166]. Treatment with ABT-263 stimulates a selective loss of older platelets, which justifies the transient thrombocytopenia detected with ABT-263 treatment [167]. The dose-limiting severe thrombocytopenia from ABT-263 quenched the interest in further clinical improvement of this compound. Pre-clinical studies of ABT-737 also revealed decreased platelet survival [169]. Hence, Bcl-xL inhibition might speed up the molecular clock and cause reduced platelet survival, the mechanism associated with ABT-263/ABT-737-induced thrombocytopenia.

\subsection{ABT-199}

ABT-199 (Venetoclax) is a promising and selective inhibitor of Bcl-2 protein, which has exhibited clinical efficacy in multiple hematological cancers [170]. ABT-199 is an inhibitor that exclusively maintains binding for Bcl-2 [171]. ABT-199 efficiently stimulates cell death in Bcl-2-dependent cancers without inducing thrombocytopenia. A single dose of ABT-199 stimulated cancer lysis syndrome in leukemia, showing potent anticancer action in vivo in humans. It is presently one of the most stimulating drugs for hematological cancers in clinical progress. Due to the important function of Bcl-2 in B-cells, clinical studies with ABT-199 presently concentrate exclusively on hematological cancers. A selective inhibitor of Bcl-2 can induce apoptosis. SCLC exhibits an elevated expression of Bcl-2 and can be liable to single-drug treatment by ABT-199. Through overexpression of Bcl-xL, ABT-199 showed pre-clinical trial activity in breast cancer cells [109] by investigation of the promise of ABT-199 as a Bcl-2 inhibitor.

Venetoclax represents the first-in-class selective, Bcl-2 inhibitor sparing platelets [169]. It exhibited a sub-nanomolar affinity for Bcl-2 with anticancer activity against NHL [63]. In studies, the Venetoclax resistant cell was recognized, and enhanced levels of Mcl-1 and elevated phosphorylation of Bcl-2 at T56 and AKT at S473 were shown. A single dose of venetoclax in patients with refractory CLL resulted in cancer lysis within $24 \mathrm{~h}$. Hence, pharmacological inhibition of Bcl-2 indicates potency for the treatment of Bcl-2-dependent cancers [169]. One study emphasizes Bcl-2 as a molecular target in particular subtypes of human T-ALL, which might be exploited via ABT-199 [172]. The novel combination of venetoclax with decitabine was efficient and well-tolerated in elderly patients with AML [173]. Venetoclax was examined in combinations with tyrosine kinase inhibitors (TKIs), including imatinib, dasatinib, and nilotinib in cells from six patient samples with blast-crisis CML [70]. All six samples were resistant to TKIs, three of them with T315I mutation. In a CML mouse model, the study further revealed that venetoclax alone or in combination was better than nilotinib in eliminating CML stem cells in vivo. To analyze the dual inhibition of Mcl-1 and Bcl-2, HHT and venetoclax were combined and investigated in seven diffuse large B-cell lymphoma cell lines [174]. Presently, venetoclax is being investigated in $>230$ clinical studies in a broad range of hematological cancers. Venetoclax has exhibited clinically consequential single-drug activity in selected lymphomas [175]. 


\section{9. $T W-37$}

TW-37 is a potential anti-tumor drug that has been identified in the prostate as well as pancreatic cancer [176]. TW-37 is a benzene-sulfonyl derivative, which originated from gossypol. One laboratory has broadly analyzed TW-37 for its activity in lymphoma, leukemia, and PCs [175,176], exhibiting anti-angiogenic activity [177]. TW-37 has a high affinity to Bcl-2. TW-37 stimulates cell death in PCs by a novel NOTCH-1 signaling pathway [178]. It is a promising inhibitor of the development of PCs because it reduces the Bcl-2 cellular pathway mechanism. TW-37 was developed as a potential therapeutic drug for the treatment of PC [139]. The anticancer activity of ApoG2, as well as TW-37, was observed to be induced by a novel pathway linking induction of PAR-4. SMI-induced cell death engaged PAR-4 in PC [179]. The detected anticancer activity of TW-37 is induced by a novel signaling pathway linking the inactivation of NOTCH-1 as well as Jagged-1 [178]. TW-37, a Bcl-2 inhibitor, exhibited synergistic results against SCC and cancer-connected endothelial cells in vivo and in vitro combined for cisplatin. Hence, it induced cell death and reduced angiogenesis, improving time for cancer failure [110].

\section{Limitations of Bcl-2 Inhibitors}

The limitations of the first $\mathrm{Bcl}-2$ family protein-targeted drugs, concerning on-target and off-target toxicities, have been overcome with the improvement and development of venetoclax [180]. ABT-737 development has been limited, and navitoclax, its orally bioavailable analog, has been developed. ABT-263 exhibited efficacy in vivo in xenograft models of leukemia as well as lymphoma [181]. Beginning from the natural compound/agent like meiogynin A, molecules particularly targeting Bcl-2/Mcl-1 [174], have been produced, synthesized, and tested in vitro, however, with limited application. Pre-clinical data supports the Bcl-2 G-quadruplex (G4)-selective move toward treating cancer and circumventing the limitations of Bcl-2 protein-based therapeutics [182]. Early generation Bcl-2 inhibitors have exhibited potency in the clinic; resistance is anticipated, as detected in several in vitro models. Hence, this resistance may occur from the up-regulation and dependence on extra anti-apoptotic proteins, which are not blocked via ABT-263/ABT-199 [183,184]. Incubation of CLL cells on stroma stimulates dramatic resistance for ABT-199 and ABT-737 that may be circumvented through combination with gossypol/ AT-101 [185,186]. Resistance for ABT-199 might arise from up-regulation of other Bcl-2 proteins; resistance may be mimicked via culturing CLL cells on CD154(+) stromal cells [185]. Venetoclax monotherapy for an extended duration may cause drug resistance or loss of dependence on the targeted protein [187]. Upregulation of MCL-1 has appeared as a general determinant of venetoclax resistance [188]. Resistance in lymphoid cells for ABT-199 has been documented [189]. Some diseases are liable to be as dependent on one Bcl-2 protein as CLL; the majority of tumors will likely require combinations of these drugs to have a significant therapeutic impact; however, these combinations may show unacceptable toxicity [190-201].

\section{Conclusions and Future Directions}

$\mathrm{Bcl}-2$ plays a central role in the regulation of apoptosis that is a major contributor to cancer development. Bcl-2 has been identified as being over-expressed in several cancers. Regulation of Bcl-2 by multiple signaling pathways, including p53, protein kinases, and signaling molecules, induces cancer development. Consistent with this examination, drugs and agents mimic major modulators of cell death that have appeared to produce positive results over the last many years. The success of any therapeutic agent depends primarily on the capability of therapeutic tools for activating cell death through targeting the anti-apoptotic proteins and initiating the expression of pro-apoptotic proteins. Bcl-2 has been recognized as a potential target for the development of novel anti-tumor drugs. However, Bcl-2 inhibitors have been shown to down-regulate Bcl-2 and up-regulate Bax, initiating apoptosis.

Several agents and drugs have been designed for targeting Bcl-2 at the mRNA and protein level. Pharmacological and cellular features of drugs targeting Bcl-2 could be 
found while exploring their prospective applications, such as chemotherapy. However, the binding affinity for blocking anti-apoptotic proteins should optimally be in clinically possible concentrations for each drug. Hence, the big challenge is investigating how best to utilize these inhibitors and which tumor types. The inhibitors of Bcl-2 are efficient as single agents, and they might be extremely beneficial when combined with additional targeted agents which induce cell death in cancer cells. Increasing the therapeutic results of Bcl-2 inhibitors of anti-apoptotic Bcl-2 protein should be done using a combination of agent which target various Bcl-2 family proteins. These treatment strategies can restore the Bcl-2 mediated apoptosis towards normality, potentially eliminating cancer cells.

Some strategies for blocking pro-survival and overexpressed Bcl-2 have been advised through the medical literature, looking at these many clinical trials. Presently several Bcl-2 inhibitors and antisense are being studied in clinical trials. Pre-clinical trials appear promising, particularly in combination with other therapeutic drugs. Continuing and designed phase II trials for describing the action of single drug and agent combinations will conclude future clinical improvement and development of Bcl-2 inhibitors.

Bcl-2 PROTAC (proteolysis targeting chimera) employs an E3 ligase for a target protein to induce its ubiquitination and degradation that potently and selectively induces the degradation of Bcl-2 and Mcl-1. PROTACs indicated reversible depletion in living cells that provide a novel promising toolkit for gain-of-function examinations to probe the dynamic functions of Bcl-2 as well as Mcl-1 in apoptosis. Hence, particular degradation of a target protein using the PROTAC for overcoming on-target drug toxicity. However, two PROTAC compounds have been reported to degrade Bcl-2/Mcl-1 selectively.

Author Contributions: Conceptualization, M.A., S.A. and M.I.H.; writing-original draft preparation, M.A., S.A., T.M. and M.I.H.; Data Analysis: G.M.H. and D.K.Y.; writing-review and editing, M.A., S.A., D.K.Y. and M.I.H.; supervision, G.M.H. and M.I.H.; project administration, M.I.H. All authors have read and agreed to the published version of the manuscript.

Funding: This work is supported by the Indian Council of Medical Research for financial support (Grant No. 45/6/2020-DDI/BMS).

Institutional Review Board Statement: Not applicable.

Informed Consent Statement: Not applicable.

Data Availability Statement: Not applicable.

Acknowledgments: S.A. sincerely thanks the Indian Council of Medical Research for the award of Research Associateship (Grant No. BMI/11(39)/2020). M.I.H. thanks the Council of Scientific and Industrial Research, India for funding [Project No. 27(0368)/20/EMR-II]. The authors express gratitude to the Department of Science and Technology, Government of India, for the FIST support (FIST program No. SR/FST/LSII/2020/782).

Conflicts of Interest: The authors declare no conflict of interest.

$\begin{array}{ll}\text { Abbreviations } \\ \text { Bcl-2 } & \text { B cell lymphoma } 2 \\ \text { BH } & \text { Bcl-2 homology domain } \\ \text { MMP } & \text { Mitochondrial membrane permeabilization } \\ \text { MBR } & \text { Major breakpoint region } \\ \text { CLL } & \text { Chronic lymphocytic leukemia } \\ \text { NSCLC } & \text { Non-small cell lung cancer } \\ \text { SCLC } & \text { Small-cell lung cancer } \\ \text { NHL } & \text { Non-Hodgkin lymphomas } \\ \text { SATB1 } & \text { Special AT-rich sequence binding protein 1 } \\ \text { IgH } & \text { Immunoglobulin heavy chain } \\ \text { TNF } & \text { Tumor necrosis factor } \\ \text { UTR } & \text { Untranslated region } \\ \text { PKC } & \text { Protein kinase C } \\ \text { EGCG } & \text { Epigallocatechin-3-gallate }\end{array}$




\section{References}

1. Kiyoshima, T.; Yoshida, H.; Wada, H.; Nagata, K.; Fujiwara, H.; Kihara, M.; Hasegawa, K.; Someya, H.; Sakai, H. Chemoresistance to concanamycin a1 in human oral squamous cell carcinoma is attenuated by an hdac inhibitor partly via suppression of bcl-2 expression. PLoS ONE 2013, 8, e80998. [CrossRef] [PubMed]

2. Gilormini, M.; Malesys, C.; Armandy, E.; Manas, P.; Guy, J.B.; Magné, N.; Rodriguez-Lafrasse, C.; Ardail, D. Preferential targeting of cancer stem cells in the radiosensitizing effect of abt-737 on hnscc. Oncotarget 2016, 7, 16731. [CrossRef]

3. Hockenbery, D.; Nuñez, G.; Milliman, C.; Schreiber, R.D.; Korsmeyer, S.J. Bcl-2 is an inner mitochondrial membrane protein that blocks programmed cell death. Nature 1990, 348, 334-336. [CrossRef]

4. Cory, S.; Adams, J.M. The bcl2 family: Regulators of the cellular life-or-death switch. Nat. Rev. Cancer 2002, 2, 647-656. [CrossRef]

5. Yin, X.M.; Oltvai, Z.N.; Korsmeyer, S.J. Bh1 and bh2 domains of bcl-2 are required for inhibition of apoptosis and heterodimerization with bax. Nature 1994, 369, 321-323. [CrossRef]

6. Nix, P.; Cawkwell, L.; Patmore, H.; Greenman, J.; Stafford, N. Bcl-2 expression predicts radiotherapy failure in laryngeal cancer. Br. J. Cancer 2005, 92, 2185-2189. [CrossRef]

7. Jackel, M.C.; Dorudian, M.A.; Marx, D.; Brinck, U.; Schauer, A.; Steiner, W. Spontaneous apoptosis in laryngeal squamous cell carcinoma is independent of bcl-2 and bax protein expression. Cancer 1999, 85, 591-599. [CrossRef]

8. Nor, J.E.; Christensen, J.; Liu, J.; Peters, M.; Mooney, D.J.; Strieter, R.M.; Polverini, P.J. Up-regulation of bcl-2 in microvascular endothelial cells enhances intratumoral angiogenesis and accelerates tumor growth. Cancer Res. 2001, 61, 2183-2188. [PubMed]

9. Cho, H.Y.; Park, H.S.; Lin, Z.; Kim, I.; Joo, K.J.; Cheon, J. BCL6 gene mutations in transitional cell carcinomas. J. Int. Med. Res. 2007, 35, 224-230. [CrossRef]

10. Hong, J.; Kim, A.J.; Park, J.S.; Lee, S.H.; Lee, K.C.; Park, J.; Sym, S.J.; Cho, E.K.; Shin, D.B.; Lee, J.H. Additional rituximab-CHOP (R-CHOP) versus involved-field radiotherapy after a brief course of R-CHOP in limited, non-bulky diffuse large B-cell lymphoma: A retrospective analysis. Korean. J. Hematol. 2010, 45, 253-259. [CrossRef] [PubMed]

11. Yoshino, T.; Shiina, H.; Urakami, S.; Kikuno, N.; Yoneda, T.; Shigeno, K.; Igawa, M. BCL-2 expression as a predictive marker of hormone-refractory prostate cancer treated with taxane-based chemotherapy. Clin. Cancer Res. 2006, 12, 6116-6124. [CrossRef] [PubMed]

12. Perini, G.F.; Ribeiro, G.N.; Neto, J.V.P.; Campos, L.T.; Hamerschlak, N. BCL-2 as therapeutic target for hematological malignancies. J. Hematol. Oncol. 2018, 11, 1-15. [CrossRef] [PubMed]

13. Tsujimoto, Y. BCL-2 family of proteins: Life-or-death switch in mitochondria. Biosci. Rep. 2002, 22, 47-58. [CrossRef] [PubMed]

14. Hong, J.; Lee, Y.; Park, Y.; Kim, S.G.; Hwang, K.H.; Park, S.H.; Jeong, J.; Kim, K.H.; Ahn, J.Y.; Park, S.; et al. Role of FDG-PET/CT in detecting lymphomatous bone marrow involvement in patients with newly diagnosed diffuse large B-cell lymphoma. Ann. Hematol. 2012, 91, 687-695. [CrossRef] [PubMed]

15. Deng, X.; Ruvolo, P.; Carr, B.; May, W.S., Jr. Survival function of erk1/2 as il-3-activated, staurosporine-resistant bcl2 kinases. Proc. Natl. Acad. Sci. USA 2000, 97, 1578-1583. [CrossRef]

16. Mai, H.; May, W.S.; Gao, F.; Jin, Z.; Deng, X. A functional role for nicotine in BCL2 phosphorylation and suppression of apoptosis. J. Biol. Chem. 2003, 278, 1886-1891. [CrossRef]

17. Hong, J.; Park, S.; Park, J.; Jang, S.J.; Ahn, H.K.; Sym, S.J.; Cho, E.K.; Shin, D.B.; Lee, J.H. CD99 expression and newly diagnosed diffuse large B-cell lymphoma treated with rituximab-CHOP immunochemotherapy. Ann. Hematol. 2012, 91, 1897-1906. [CrossRef]

18. Miyashita, T.; Krajewski, S.; Krajewska, M.; Wang, H.G.; Lin, H.K.; Liebermann, D.A.; Hoffman, B.; Reed, J.C. Tumor suppressor p53 is a regulator of BCL-2 and bax gene expression in vitro and in vivo. Oncogene 1994, 9, 1799-1805.

19. Miyashita, T.; Reed, J.C. Tumor suppressor p53 is a direct transcriptional activator of the human bax gene. Cell 1995, 80, 293-299.

20. Sakuragi, N.; Salah-eldin, A.E.; Watari, H.; Itoh, T.; Inoue, S.; Moriuchi, T.; Fujimoto, S. Bax, BCL-2, and p53 expression in endometrial cancer. Gynecol. Oncol. 2002, 86, 288-296. [CrossRef]

21. Mortenson, M.M.; Schlieman, M.G.; Virudalchalam, S.; Bold, R.J. Overexpression of BCL-2 results in activation of the akt/nf-kb cell survival pathway. J. Surg. Res. 2003, 114, 302. [CrossRef]

22. Hong, J.; Park, S.; Park, J.; Kim, H.S.; Kim, K.H.; Ahn, J.Y.; Rim, M.Y.; Jung, M.; Sym, S.J.; Cho, E.K.; et al. Evaluation of prognostic values of clinical and histopathologic characteristics in diffuse large B-cell lymphoma treated with rituximab, cyclophosphamide, doxorubicin, vincristine, and prednisolone therapy. Leuk. Lymphoma 2011, 52, 1904-1912. [CrossRef]

23. Cook, S.J.; Stuart, K.; Gilley, R.; Sale, M.J. Control of cell death and mitochondrial fission by erk1/2 map kinase signalling. FEBS J. 2017, 284, 4177-4195. [CrossRef]

24. Lee, H.G.; Kim, S.Y.; Kim, I.; Kim, Y.K.; Kim, J.A.; Kim, Y.S.; Lee, H.S.; Park, J.; Kim, S.J.; Shim, H.; et al. Prediction of survival by applying current prognostic models in diffuse large B-cell lymphoma treated with R-CHOP followed by autologous transplantation. Blood. Res. 2015, 50, 160-166. [CrossRef]

25. Lee, J.; Kang, Y.J.; Ahn, J.; Song, S.H. Indolent B-Cell Lymphoid Malignancy in the Spleen of a Man Who Handled Benzene: Splenic Marginal Zone Lymphoma. Saf. Health Work 2017, 8, 315-317. [CrossRef] [PubMed]

26. Lee, S.H.; Kim, H.C.; Kim, Y.J. B-Cell Lymphoma in a Patient With a History of Foreign Body Injection. J. Craniofac. Surg. 2017, 28, 504-505. [CrossRef] [PubMed] 
27. Lee, K.C.; Lee, S.H.; Sung, K.; Ahn, S.H.; Choi, J.; Lee, S.H.; Lee, J.H.; Hong, J.; Park, S.H. A Case of Primary Breast Diffuse Large B-Cell Lymphoma Treated with Chemotherapy Followed by Elective Field Radiation Therapy: A Brief Treatment Pattern Review from a Radiation Oncologist's Point of View. Case. Rep. Oncol. Med. 2015, 2015, 907978. [CrossRef] [PubMed]

28. Lee, S.P.; Park, S.; Park, J.; Hong, J.; Ko, Y.H. Clinicopathologic characteristics of CD99-positive diffuse large B-cell lymphoma. Acta Haematol. 2011, 125, 167-174. [CrossRef] [PubMed]

29. Subedi, L.; Gaire, B.P.; Do, M.H.; Lee, T.H.; Kim, S.Y. Anti-neuroinflammatory and neuroprotective effects of the Lindera neesiana fruit in vitro. Phytomedicine 2016, 23, 872-881. [CrossRef] [PubMed]

30. Lai, D.; Visser-Grieve, S.; Yang, X. Tumour suppressor genes in chemotherapeutic drug response. Biosci. Rep. 2012, 32, 361-374. [CrossRef]

31. Oda, E.; Ohki, R.; Murasawa, H.; Nemoto, J.; Shibue, T.; Yamashita, T.; Tokino, T.; Taniguchi, T.; Tanaka, N. Noxa, a BH3-only member of the BCL-2 family and candidate mediator of p53-induced apoptosis. Science 2000, 288, 1053-1058. [CrossRef]

32. Lee, Y.; Hwang, K.H.; Hong, J.; Park, J.; Lee, J.H.; Ahn, J.Y.; Kim, J.H.; Lee, H.; Kim, S.G.; Shin, J.Y. Usefulness of (18)F-FDG PET/CT for the Evaluation of Bone Marrow Involvement in Patients with High-Grade Non-Hodgkin's Lymphoma. Nucl. Med. Mol. Imaging 2012, 46, 269-277. [CrossRef]

33. Hong, J.; Yoon, H.H.; Ahn, H.K.; Sym, S.J.; Park, J.; Park, P.W.; Ahn, J.Y.; Park, S.; Cho, E.K.; Shin, D.B.; et al. Prognostic role of serum lactate dehydrogenase beyond initial diagnosis: A retrospective analysis of patients with diffuse large B cell lymphoma. Acta Haematol. 2013, 130, 305-311. [CrossRef]

34. Jang, H.R.; Song, M.K.; Chung, J.S.; Yang, D.H.; Lee, J.O.; Hong, J.; Cho, S.H.; Kim, S.J.; Shin, D.H.; Park, Y.J.; et al. Maximum standardized uptake value on positron emission tomography/computed tomography predicts clinical outcome in patients with relapsed or refractory diffuse large B-cell lymphoma. Blood Res. 2015, 50, 97-102. [CrossRef]

35. Lee, Y.S.; Jun, H.S. Anti-diabetic actions of glucagon-like peptide-1 on pancreatic beta-cells. Metabolism 2014, 63, 9-19. [CrossRef] [PubMed]

36. Jeong, E.K.; Jang, H.J.; Kim, S.S.; Oh, M.Y.; Lee, D.H.; Eom, D.W.; Kang, K.S.; Kwan, H.C.; Ham, J.Y.; Park, C.S.; et al. Protective effect of eupatilin against renal ischemia-reperfusion injury in mice. Transplant. Proc. 2015, 47, 757-762. [CrossRef] [PubMed]

37. Jung, M.Y.; Seo, C.S.; Baek, S.E.; Lee, J.; Shin, M.S.; Kang, K.S.; Lee, S.; Yoo, J.E. Analysis and Identification of Active Compounds from Gami-Soyosan Toxic to MCF-7 Human Breast Adenocarcinoma Cells. Biomolecules 2019, 9, 272. [CrossRef] [PubMed]

38. Reed, J.C. Pro-apoptotic multi-domain BCL-2/bax-family proteins: Mechanisms, physiological roles, and therapeutic opportunities. Cell Death Differ. 2006, 13, 1378-1386. [CrossRef]

39. Camisasca, D.R.; Honorato, J.; Bernardo, V.; da Silva, L.E.; da Fonseca, E.C.; de Faria, P.A.; Dias, F.L.; Lourenco Sde, Q. Expression of BCL-2 family proteins and associated clinicopathologic factors predict survival outcome in patients with oral squamous cell carcinoma. Oral Oncol. 2009, 45, 225-233. [CrossRef]

40. Strasser, A.; Huang, D.C.; Vaux, D.L. The role of the BCL-2/ced-9 gene family in cancer and general implications of defects in cell death control for tumourigenesis and resistance to chemotherapy. Biochim. Biophys. Acta 1997, 1333, F151-F178. [CrossRef]

41. Jordan, R.C.; Catzavelos, G.C.; Barrett, A.W.; Speight, P.M. Differential expression of BCL-2 and bax in squamous cell carcinomas of the oral cavity. Eur. J. Cancer Part B Oral Oncol. 1996, 32, 394-400. [CrossRef]

42. Xie, X.; Clausen, O.P.; de Angelis, P.; Boysen, M. The prognostic value of spontaneous apoptosis, bax, BCL-2, and p53 in oral squamous cell carcinoma of the tongue. Cancer 1999, 86, 913-920. [CrossRef]

43. Huang, D.C.; Strasser, A. BH3-only proteins-essential initiators of apoptotic cell death. Cell 2000, 103, 839-842. [CrossRef]

44. Lavieille, J.P.; Gazzeri, S.; Riva, C.; Reyt, E.; Brambilla, C.; Brambilla, E. P53 mutations and p53, waf-1, bax and BCL-2 expression in field cancerization of the head and neck. Anticancer Res. 1998, 18, 4741-4749.

45. Kim, J.; Hong, J.; Kim, S.G.; Hwang, K.H.; Kim, M.; Ahn, H.K.; Sym, S.J.; Park, J.; Cho, E.K.; Shin, D.B.; et al. Prognostic Value of Metabolic Tumor Volume Estimated by (18) F-FDG Positron Emission Tomography/Computed Tomography in Patients with Diffuse Large B-Cell Lymphoma of Stage II or III Disease. Nucl. Med. Mol. Imaging 2014, 48, 187-195. [CrossRef]

46. Quinn, B.A.; Dash, R.; Azab, B.; Sarkar, S.; Das, S.K.; Kumar, S.; Oyesanya, R.A.; Dasgupta, S.; Dent, P.; Grant, S.; et al. Targeting mcl-1 for the therapy of cancer. Expert Opin. Investig. Drugs 2011, 20, 1397-1411. [CrossRef]

47. Quinn, L.M.; Richardson, H. Bcl-2 in cell cycle regulation. Cell Cycle 2004, 3, 7-9. [CrossRef]

48. Ma, C.; Zhang, J.; Durrin, L.K.; Lv, J.; Zhu, D.; Han, X.; Sun, Y. The BCL2 major breakpoint region (mbr) regulates gene expression. Oncogene 2007, 26, 2649-2657. [CrossRef] [PubMed]

49. Chipuk, J.E.; Moldoveanu, T.; Llambi, F.; Parsons, M.J.; Green, D.R. The BCL-2 family reunion. Mol. Cell 2010, 37, 299-310. [CrossRef] [PubMed]

50. Youle, R.J.; Strasser, A. The BCL-2 protein family: Opposing activities that mediate cell death. Nat. Rev. Mol. Cell Biol. 2008, 9 , 47-59. [CrossRef] [PubMed]

51. Kim, S.S.; Jang, H.J.; Oh, M.Y.; Lee, J.H.; Kang, K.S. Tetrahydrocurcumin Enhances Islet Cell Function and Attenuates Apoptosis in Mouse Islets. Transplant. Proc. 2018, 50, 2847-2853. [CrossRef]

52. Reed, J.C.; Cuddy, M.; Slabiak, T.; Croce, C.M.; Nowell, P.C. Oncogenic potential of BCL-2 demonstrated by gene transfer. Nature 1988, 336, 259-261. [CrossRef] [PubMed]

53. Yunis, J.J.; Mayer, M.G.; Arnesen, M.A.; Aeppli, D.P.; Oken, M.M.; Frizzera, G. BCL-2 and other genomic alterations in the prognosis of large-cell lymphoma. N. Engl. J. Med. 1989, 320, 1047-1054. [CrossRef] [PubMed] 
54. Bakhshi, A.; Jensen, J.P.; Goldman, P.; Wright, J.J.; McBride, O.W.; Epstein, A.L.; Korsmeyer, S.J. Cloning the chromosomal breakpoint of $\mathrm{t}(14 ; 18)$ human lymphomas: Clustering around jh on chromosome 14 and near a transcriptional unit on 18 . Cell 1985, 41, 899-906. [CrossRef]

55. Cleary, M.L.; Smith, S.D.; Sklar, J. Cloning and structural analysis of cdnas for BCL-2 and a hybrid BCL-2/immunoglobulin transcript resulting from the $t(14 ; 18)$ translocation. Cell 1986, 47, 19-28. [CrossRef]

56. Tsujimoto, Y.; Finger, L.R.; Yunis, J.; Nowell, P.C.; Croce, C.M. Cloning of the chromosome breakpoint of neoplastic b cells with the $t(14 ; 18)$ chromosome translocation. Science 1984, 226, 1097-1099. [CrossRef]

57. Limpens, J.; de Jong, D.; van Krieken, J.H.; Price, C.G.; Young, B.D.; van Ommen, G.J.; Kluin, P.M. BCL-2/jh rearrangements in benign lymphoid tissues with follicular hyperplasia. Oncogene 1991, 6, 2271-2276.

58. Limpens, J.; Stad, R.; Vos, C.; de Vlaam, C.; de Jong, D.; van Ommen, G.J.; Schuuring, E.; Kluin, P.M. Lymphoma-associated translocation $\mathrm{t}(14 ; 18)$ in blood b cells of normal individuals. Blood 1995, 85, 2528-2536. [CrossRef] [PubMed]

59. Vaux, D.L.; Cory, S.; Adams, J.M. BCL-2 gene promotes haemopoietic cell survival and cooperates with c-myc to immortalize pre-b cells. Nature 1988, 335, 440-442. [CrossRef] [PubMed]

60. McDonnell, T.J.; Deane, N.; Platt, F.M.; Nunez, G.; Jaeger, U.; McKearn, J.P.; Korsmeyer, S.J. BCL-2-immunoglobulin transgenic mice demonstrate extended b cell survival and follicular lymphoproliferation. Cell 1989, 57, 79-88. [CrossRef]

61. McDonnell, T.J.; Korsmeyer, S.J. Progression from lymphoid hyperplasia to high-grade malignant lymphoma in mice transgenic for the $\mathrm{t}(14 ; 18)$. Nature 1991, 349, 254-256. [CrossRef]

62. Cleary, M.; Rosenberg, S.A. The BCL-2 gene, follicular lymphoma, and hodgkin's disease. J. Natl. Cancer Inst. 1990, 82, 808-809. [CrossRef]

63. Horning, S.J.; Rosenberg, S.A. The natural history of initially untreated low-grade non-hodgkin's lymphomas. N. Engl. J. Med. 1984, 311, 1471-1475. [CrossRef]

64. Minn, A.J.; Velez, P.; Schendel, S.L.; Liang, H.; Muchmore, S.W.; Fesik, S.W.; Fill, M.; Thompson, C.B. BCL- $x_{L}$ forms an ion channel in synthetic lipid membranes. Nature 1997, 385, 353-357. [CrossRef]

65. Ikegaki, N.; Katsumata, M.; Minna, J.; Tsujimoto, Y. Expression of BCL-2 in small cell lung carcinoma cells. Cancer Res. 1994, 54, 6-8. [PubMed]

66. Tsujimoto, Y. Stress-resistance conferred by high level of BCL-2 alpha protein in human b lymphoblastoid cell. Oncogene 1989, 4, 1331-1336. [PubMed]

67. Beham, A.; Marin, M.C.; Fernandez, A.; Herrmann, J.; Brisbay, S.; Tari, A.M.; Lopez-Berestein, G.; Lozano, G.; Sarkiss, M.; McDonnell, T.J. BCL-2 inhibits p53 nuclear import following DNA damage. Oncogene 1997, 15, 2767-2772. [CrossRef] [PubMed]

68. Massaad, C.A.; Portier, B.P.; Taglialatela, G. Inhibition of transcription factor activity by nuclear compartment-associated BCL-2. J. Biol. Chem. 2004, 279, 54470-54478. [CrossRef]

69. Seto, M.; Jaeger, U.; Hockett, R.D.; Graninger, W.; Bennett, S.; Goldman, P.; Korsmeyer, S.J. Alternative promoters and exons, somatic mutation and deregulation of the BCL-2-ig fusion gene in lymphoma. EMBO J. 1988, 7, 123-131. [CrossRef]

70. Dwivedi, G.R.; Rai, R.; Pratap, R.; Singh, K.; Pati, S.; Sahu, S.N.; Kant, R.; Darokar, M.P.; Yadav, D.K. Drug resistance reversal potential of multifunctional thieno[3,2-c]pyran via potentiation of antibiotics in MDR P. aeruginosa. Biomed. Pharmacother. 2021, 142, 112084. [CrossRef]

71. Lee, D.; Kim, K.H.; Lee, W.Y.; Kim, C.E.; Sung, S.H.; Kang, K.B.; Kang, K.S. Multiple Targets of 3-Dehydroxyceanothetric Acid 2-Methyl Ester to Protect Against Cisplatin-Induced Cytotoxicity in Kidney Epithelial LLC-PK1 Cells. Molecules 2019, 24, 878. [CrossRef]

72. Zhang, J.; Ma, C.; Han, X.; Durrin, L.K.; Sun, Y. The BCL-2 major breakpoint region (mbr) possesses transcriptional regulatory function. Gene 2006, 379, 127-131. [CrossRef]

73. Gong, F.; Sun, L.; Wang, Z.; Shi, J.; Li, W.; Wang, S.; Han, X.; Sun, Y. The BCL2 gene is regulated by a special at-rich sequence binding protein 1-mediated long range chromosomal interaction between the promoter and the distal element located within the 3'-utr. Nucleic Acids Res. 2011, 39, 4640-4652. [CrossRef]

74. Dong, L.; Wang, W.; Wang, F.; Stoner, M.; Reed, J.C.; Harigai, M.; Samudio, I.; Kladde, M.P.; Vyhlidal, C.; Safe, S. Mechanisms of transcriptional activation of BCL-2 gene expression by 17beta-estradiol in breast cancer cells. J. Biol. Chem. 1999, 274, 32099-32107. [CrossRef] [PubMed]

75. Chen-Levy, Z.; Nourse, J.; Cleary, M.L. The BCL-2 candidate proto-oncogene product is a 24-kilodalton integral-membrane protein highly expressed in lymphoid cell lines and lymphomas carrying the t(14;18) translocation. Mol. Cell. Biol. 1989, 9 , 701-710. [CrossRef] [PubMed]

76. Liu, Z.; Wild, C.; Ding, Y.; Ye, N.; Chen, H.; Wold, E.A.; Zhou, J. Bh4 domain of BCL-2 as a novel target for cancer therapy. Drug Discov. Today 2016, 21, 989-996. [CrossRef]

77. Petros, A.M.; Medek, A.; Nettesheim, D.G.; Kim, D.H.; Yoon, H.S.; Swift, K.; Matayoshi, E.D.; Oltersdorf, T.; Fesik, S.W. Solution structure of the anti-apoptotic protein BCL-2. Proc. Natl. Acad. Sci. USA 2001, 98, 3012-3017. [CrossRef]

78. Huang, D.C.; Adams, J.M.; Cory, S. The conserved n-terminal bh4 domain of BCL-2 homologues is essential for inhibition of apoptosis and interaction with ced-4. EMBO J. 1998, 17, 1029-1039. [CrossRef]

79. Hanada, M.; Aime-Sempe, C.; Sato, T.; Reed, J.C. Structure-function analysis of BCL-2 protein. Identification of conserved domains important for homodimerization with BCL-2 and heterodimerization with bax. J. Biol. Chem. 1995, 270, 11962-11969. [CrossRef] [PubMed] 
80. Bruey, J.M.; Bruey-Sedano, N.; Luciano, F.; Zhai, D.; Balpai, R.; Xu, C.; Kress, C.L.; Bailly-Maitre, B.; Li, X.; Osterman, A.; et al. Bcl-2 and BCL-xl regulate proinflammatory caspase-1 activation by interaction with nalp1. Cell 2007, 129, 45-56. [CrossRef] [PubMed]

81. Wang, H.G.; Rapp, U.R.; Reed, J.C. Bcl-2 targets the protein kinase raf-1 to mitochondria. Cell 1996, 87, 629-638. [CrossRef]

82. Jin, Z.; May, W.S.; Gao, F.; Flagg, T.; Deng, X. Bcl2 suppresses DNA repair by enhancing c-myc transcriptional activity. J. Biol. Chem. 2006, 281, 14446-14456. [CrossRef] [PubMed]

83. Hardwick, J.M.; Soane, L. Multiple functions of BCL-2 family proteins. Cold Spring Harb. Perspect. Biol. 2013, 5, a008722. [CrossRef]

84. Raffo, A.J.; Perlman, H.; Chen, M.W.; Day, M.L.; Streitman, J.S.; Buttyan, R. Overexpression of BCL-2 protects prostate cancer cells from apoptosis in vitro and confers resistance to androgen depletion in vivo. Cancer Res. 1995, 55, 4438-4445. [PubMed]

85. Campbell, K.J.; Tait, S.W.G. Targeting BCL-2 regulated apoptosis in cancer. Open Biol. 2018, 8, 180002. [CrossRef]

86. Fulda, S.; Meyer, E.; Debatin, K.M. Inhibition of trail-induced apoptosis by BCL-2 overexpression. Oncogene 2002, 21, 2283-2294. [CrossRef]

87. Mishra, R. Glycogen synthase kinase 3 beta: Can it be a target for oral cancer. Mol. Cancer 2010, 9, 144. [CrossRef]

88. Hanahan, D.; Weinberg, R.A. The hallmarks of cancer. Cell 2000, 100, 57-70. [CrossRef]

89. Deng, X.; Gao, F.; Flagg, T.; May, W.S., Jr. Mono- and multisite phosphorylation enhances BCL2's anti-apoptotic function and inhibition of cell cycle entry functions. Proc. Natl. Acad. Sci. USA 2004, 101, 153-158. [CrossRef]

90. Zhou, M.; Zhang, Q.; Zhao, J.; Liao, M.; Wen, S.; Yang, M. Phosphorylation of BCL-2 plays an important role in glycochenodeoxycholate-induced survival and chemoresistance in hcc. Oncol. Rep. 2017, 38, 1742-1750. [CrossRef]

91. Eischen, C.M.; Packham, G.; Nip, J.; Fee, B.E.; Hiebert, S.W.; Zambetti, G.P.; Cleveland, J.L. Bcl-2 is an apoptotic target suppressed by both c-myc and e2f-1. Oncogene 2001, 20, 6983-6993. [CrossRef]

92. Gautschi, O.; Tschopp, S.; Olie, R.A.; Leech, S.H.; Simoes-Wust, A.P.; Ziegler, A.; Baumann, B.; Odermatt, B.; Hall, J.; Stahel, R.A.; et al. activity of a novel BCL-2/BCL-xl-bispecific antisense oligonucleotide against tumors of diverse histologic origins. J. Natl. Cancer Inst. 2001, 93, 463-471. [CrossRef] [PubMed]

93. Jiang, Z.; Zheng, X.; Rich, K.M. Down-regulation of BCL-2 and BCL-xl expression with bispecific antisense treatment in glioblastoma cell lines induce cell death. J. Neurochem. 2003, 84, 273-281. [CrossRef]

94. Zangemeister-Wittke, U.; Leech, S.H.; Olie, R.A.; Simoes-Wust, A.P.; Gautschi, O.; Luedke, G.H.; Natt, F.; Haner, R.; Martin, P.; Hall, J.; et al. A novel bispecific antisense oligonucleotide inhibiting both BCL-2 and BCL-xl expression efficiently induces apoptosis in tumor cells. Clin. Cancer Res. 2000, 6, 2547-2555. [PubMed]

95. Wang, J.L.; Zhang, Z.J.; Choksi, S.; Shan, S.; Lu, Z.; Croce, C.M.; Alnemri, E.S.; Korngold, R.; Huang, Z. Cell permeable Bcl-2 binding peptides: A chemical approach to apoptosis induction in tumor cells. Cancer Res. 2000, 60, 1498-1502. [PubMed]

96. Degterev, A.; Lugovskoy, A.; Cardone, M.; Mulley, B.; Wagner, G.; Mitchison, T.; Yuan, J. Identification of small-molecule inhibitors of interaction between the BH3 domain and BCL-xl. Nat. Cell Biol. 2001, 3, 173-182. [CrossRef] [PubMed]

97. Tzung, S.P.; Kim, K.M.; Basanez, G.; Giedt, C.D.; Simon, J.; Zimmerberg, J.; Zhang, K.Y.; Hockenbery, D.M. Antimycin a mimics a cell-death-inducing BCL-2 homology domain 3. Nat. Cell Biol. 2001, 3, 183-191. [CrossRef] [PubMed]

98. Lowe, S.L.; Rubinchik, S.; Honda, T.; McDonnell, T.J.; Dong, J.Y.; Norris, J.S. Prostate-specific expression of bax delivered by an adenoviral vector induces apoptosis in lncap prostate cancer cells. Gene Ther. 2001, 8, 1363-1371. [CrossRef] [PubMed]

99. O'Brien, S.M.; Cunningham, C.C.; Golenkov, A.K.; Turkina, A.G.; Novick, S.C.; Rai, K.R. Phase I to II multicenter study of oblimersen sodium, a BCL-2 antisense oligonucleotide, in patients with advanced chronic lymphocytic leukemia. J. Clin. Oncol. 2005, 23, 7697-7702. [CrossRef] [PubMed]

100. Rudin, C.M.; Salgia, R.; Wang, X.; Hodgson, L.D.; Masters, G.A.; Green, M.; Vokes, E.E. Randomized phase II study of carboplatin and etoposide with or without the BCL-2 antisense oligonucleotide oblimersen for extensive-stage small-cell lung cancer: Calgb 30103. J. Clin. Oncol. 2008, 26, 870-876. [CrossRef] [PubMed]

101. Zhai, D.; Jin, C.; Satterthwait, A.C.; Reed, J.C. Comparison of chemical inhibitors of anti-apoptotic BCL-2-family proteins. Cell Death Differ. 2006, 13, 1419-1421. [CrossRef] [PubMed]

102. Masuda, M.; Suzui, M.; Weinstein, I.B. Effects of epigallocatechin-3-gallate on growth, epidermal growth factor receptor signaling pathways, gene expression, and chemosensitivity in human head and neck squamous cell carcinoma cell lines. Clin. Cancer Res. 2001, 7, 4220-4229. [PubMed]

103. Leone, M.; Zhai, D.; Sareth, S.; Kitada, S.; Reed, J.C.; Pellecchia, M. Cancer prevention by tea polyphenols is linked to their direct inhibition of anti-apoptotic BCL-2-family proteins. Cancer Res. 2003, 63, 8118-8121.

104. Li, R.; Zang, Y.; Li, C.; Patel, N.S.; Grandis, J.R.; Johnson, D.E. Abt-737 synergizes with chemotherapy to kill head and neck squamous cell carcinoma cells via a noxa-mediated pathway. Mol. Pharmacol. 2009, 75, 1231-1239. [CrossRef] [PubMed]

105. Vogler, M. Targeting BCL2-proteins for the treatment of solid tumours. Adv. Med. 2014, 2014, 943648. [CrossRef] [PubMed]

106. Roberts, A.W.; Seymour, J.F.; Brown, J.R.; Wierda, W.G.; Kipps, T.J.; Khaw, S.L.; Carney, D.A.; He, S.Z.; Huang, D.C.; Xiong, H.; et al. Substantial susceptibility of chronic lymphocytic leukemia to BCL2 inhibition: Results of a phase i study of navitoclax in patients with relapsed or refractory disease. J. Clin. Oncol. 2012, 30, 488-496. [CrossRef]

107. Tse, C.; Shoemaker, A.R.; Adickes, J.; Anderson, M.G.; Chen, J.; Jin, S.; Johnson, E.F.; Marsh, K.C.; Mitten, M.J.; Nimmer, P.; et al. Abt-263: A potent and orally bioavailable BCL-2 family inhibitor. Cancer Res. 2008, 68, 3421-3428. [CrossRef]

108. Pan, R.; Hogdal, L.J.; Benito, J.M.; Bucci, D.; Han, L.; Borthakur, G.; Cortes, J.; DeAngelo, D.J.; Debose, L.; Mu, H. Selective Bcl-2 inhibition by abt-199 causes on-target cell death in acute myeloid leukemia. Cancer Discov. 2014, 4, 362-375. [CrossRef] 
109. Vaillant, F.; Merino, D.; Lee, L.; Breslin, K.; Pal, B.; Ritchie, M.E.; Smyth, G.K.; Christie, M.; Phillipson, L.J.; Burns, C.J.; et al. Targeting BCL-2 with the BH3 mimetic abt-199 in estrogen receptor-positive breast cancer. Cancer Cell 2013, 24, 120-129. [CrossRef]

110. Ashimori, N.; Zeitlin, B.D.; Zhang, Z.; Warner, K.; Turkienicz, I.M.; Spalding, A.C.; Teknos, T.N.; Wang, S.; Nor, J.E. Tw-37, a small-molecule inhibitor of BCL-2, mediates s-phase cell cycle arrest and suppresses head and neck tumor angiogenesis. Mol. Cancer Ther. 2009, 8, 893-903. [CrossRef]

111. Wang, Z.; Song, W.; Aboukameel, A.; Mohammad, M.; Wang, G.; Banerjee, S.; Kong, D.; Wang, S.; Sarkar, F.H.; Mohammad, R.M. Tw-37, a small-molecule inhibitor of BCL-2, inhibits cell growth and invasion in pancreatic cancer. Int. J. Cancer 2008, 123, 958-966. [CrossRef]

112. Oliver, C.L.; Bauer, J.A.; Wolter, K.G.; Ubell, M.L.; Narayan, A.; O'Connell, K.M.; Fisher, S.G.; Wang, S.; Wu, X.; Ji, M.; et al. In vitro effects of the $\mathrm{BH} 3$ mimetic, (-)-gossypol, on head and neck squamous cell carcinoma cells. Clin. Cancer Res. 2004, 10, 7757-7763. [CrossRef]

113. Chen, J.; Freeman, A.; Liu, J.; Dai, Q.; Lee, R.M. The apoptotic effect of ha14-1, a BCL-2-interacting small molecular compound, requires bax translocation and is enhanced by pk11195. Mol. Cancer Ther. 2002, 1, 961-967. [PubMed]

114. Huang, S.; Okumura, K.; Sinicrope, F.A. BH3 mimetic obatoclax enhances trail-mediated apoptosis in human pancreatic cancer cells. Clin. Cancer Res. 2009, 15, 150-159. [CrossRef] [PubMed]

115. Wang, J.L.; Liu, D.; Zhang, Z.-J.; Shan, S.; Han, X.; Srinivasula, S.M.; Croce, C.M.; Alnemri, E.S.; Huang, Z. Structure-based discovery of an organic compound that binds BCL-2 protein and induces apoptosis of tumor cells. Proc. Natl. Acad. Sci. USA 2000, 97, 7124-7129. [CrossRef]

116. Sinicrope, F.A.; Penington, R.C.; Tang, X.M. Tumor necrosis factor-related apoptosis-inducing ligand-induced apoptosis is inhibited by BCL-2 but restored by the small molecule BCL-2 inhibitor, ha 14-1, in human colon cancer cells. Clin. Cancer Res. 2004, 10, 8284-8292. [CrossRef]

117. Hoffmann, T.K.; Leenen, K.; Hafner, D.; Balz, V.; Gerharz, C.D.; Grund, A.; Ballo, H.; Hauser, U.; Bier, H. Anti-tumor activity of protein kinase c inhibitors and cisplatin in human head and neck squamous cell carcinoma lines. Anticancer Drugs 2002, 13, 93-100. [CrossRef] [PubMed]

118. Casara, P.; Davidson, J.; Claperon, A.; Le Toumelin-Braizat, G.; Vogler, M.; Bruno, A.; Chanrion, M.; Lysiak-Auvity, G.; Le Diguarher, T.; Starck, J.B.; et al. S55746 is a novel orally active BCL-2 selective and potent inhibitor that impairs hematological tumor growth. Oncotarget 2018, 9, 20075-20088. [CrossRef]

119. Emi, M.; Kim, R.; Tanabe, K.; Uchida, Y.; Toge, T. Targeted therapy against BCL-2-related proteins in breast cancer cells. Breast Cancer Res. 2005, 7, R940-R952. [CrossRef]

120. Maiuri, M.C.; Le Toumelin, G.; Criollo, A.; Rain, J.C.; Gautier, F.; Juin, P.; Tasdemir, E.; Pierron, G.; Troulinaki, K.; Tavernarakis, N.; et al. Functional and physical interaction between BCL-x(l) and a BH3-like domain in beclin-1. EMBO J. 2007, 26, 2527-2539. [CrossRef]

121. Kim, R.; Emi, M.; Matsuura, K.; Tanabe, K. Antisense and nonantisense effects of antisense BCL-2 on multiple roles of BCL-2 as a chemosensitizer in cancer therapy. Cancer Gene Ther. 2007, 14, 1-11. [CrossRef]

122. Moreira, J.N.; Santos, A.; Simoes, S. Bcl-2-targeted antisense therapy (oblimersen sodium): Towards clinical reality. Rev. Recent Clin. Trials 2006, 1, 217-235. [CrossRef]

123. Marshall, J.; Chen, H.; Yang, D.; Figueira, M.; Bouker, K.B.; Ling, Y.; Lippman, M.; Frankel, S.R.; Hayes, D.F. A phase I trial of a BCL-2 antisense (g3139) and weekly docetaxel in patients with advanced breast cancer and other solid tumors. Ann. Oncol. 2004, 15, 1274-1283. [CrossRef]

124. Tolcher, A.W. Targeting BCL-2 protein expression in solid tumors and hematologic malignancies with antisense oligonucleotides. Clin. Adv. Hematol. Oncol. 2005, 3, 635-642.

125. Withers, W.A.; Carruth, F.E. Gossypol-A toxic substance in cottonseed. A preliminary note. Science 1915, 41, 324. [CrossRef]

126. Ohuchi, K.; Watanabe, M.; Hirasawa, N.; Tsurufuji, S.; Ozeki, T.; Fujiki, H. Inhibition by gossypol of tumor promoter-induced arachidonic acid metabolism in rat peritoneal macrophages. Biochim. Biophys. Acta 1988, 971, 85-91. [PubMed]

127. Hu, F.; Mah, K.; Teramura, D.J. Gossypol effects on cultured normal and malignant melanocytes. In Vitro Cell. Dev. Biol. 1986, 22, 583-588. [CrossRef] [PubMed]

128. Huang, Y.W.; Wang, L.S.; Chang, H.L.; Ye, W.; Dowd, M.K.; Wan, P.J.; Lin, Y.C. Molecular mechanisms of (-)-gossypol-induced apoptosis in human prostate cancer cells. Anticancer Res. 2006, 26, 1925-1933. [PubMed]

129. Volate, S.R.; Kawasaki, B.T.; Hurt, E.M.; Milner, J.A.; Kim, Y.S.; White, J.; Farrar, W.L. Gossypol induces apoptosis by activating p53 in prostate cancer cells and prostate tumor-initiating cells. Mol. Cancer Ther. 2010, 9, 461-470. [CrossRef]

130. Bushunow, P.; Reidenberg, M.M.; Wasenko, J.; Winfield, J.; Lorenzo, B.; Lemke, S.; Himpler, B.; Corona, R.; Coyle, T. Gossypol treatment of recurrent adult malignant gliomas. J. Neurooncol. 1999, 43, 79-86. [CrossRef]

131. Kang, M.H.; Reynolds, C.P. Bcl-2 inhibitors: Targeting mitochondrial apoptotic pathways in cancer therapy. Clin. Cancer Res. 2009, 15, 1126-1132. [CrossRef]

132. Pan, J.; Cheng, C.; Verstovsek, S.; Chen, Q.; Jin, Y.; Cao, Q. The BH3-mimetic gx15-070 induces autophagy, potentiates the cytotoxicity of carboplatin and 5-fluorouracil in esophageal carcinoma cells. Cancer Lett. 2010, 293, 167-174. [CrossRef]

133. Voss, V.; Senft, C.; Lang, V.; Ronellenfitsch, M.W.; Steinbach, J.P.; Seifert, V.; Kogel, D. The pan-BCL-2 inhibitor (-)-gossypol triggers autophagic cell death in malignant glioma. Mol. Cancer Res. 2010, 8, 1002-1016. [CrossRef] 
134. Simon, G.; Sharma, A.; Li, X.; Hazelton, T.; Walsh, F.; Williams, C.; Chiappori, A.; Haura, E.; Tanvetyanon, T.; Antonia, S.; et al. Feasibility and efficacy of molecular analysis-directed individualized therapy in advanced non-small-cell lung cancer. J. Clin. Oncol. 2007, 25, 2741-2746. [CrossRef]

135. Olberding, K.E.; Wang, X.; Zhu, Y.; Pan, J.; Rai, S.N.; Li, C. Actinomycin d synergistically enhances the efficacy of the BH3 mimetic abt-737 by downregulating mcl-1 expression. Cancer Biol. Ther. 2010, 10, 918-929. [CrossRef]

136. Trudel, S.; Li, Z.H.; Rauw, J.; Tiedemann, R.E.; Wen, X.Y.; Stewart, A.K. Pre-clinical studies of the pan-BCL inhibitor obatoclax (gx015-070) in multiple myeloma. Blood 2007, 109, 5430-5438. [CrossRef] [PubMed]

137. Smoot, R.L.; Blechacz, B.R.; Werneburg, N.W.; Bronk, S.F.; Sinicrope, F.A.; Sirica, A.E.; Gores, G.J. A bax-mediated mechanism for obatoclax-induced apoptosis of cholangiocarcinoma cells. Cancer Res. 2010, 70, 1960-1969. [CrossRef]

138. Perez-Galan, P.; Roue, G.; Villamor, N.; Montserrat, E.; Campo, E.; Colomer, D. The proteasome inhibitor bortezomib induces apoptosis in mantle-cell lymphoma through generation of ros and noxa activation independent of p53 status. Blood 2006, 107, 257-264. [CrossRef]

139. Masood, A.; Azmi, A.S.; Mohammad, R.M. Small molecule inhibitors of BCL-2 family proteins for pancreatic cancer therapy. Cancers 2011, 3, 1527-1549. [CrossRef] [PubMed]

140. Lambert, J.D.; Yang, C.S. Cancer chemopreventive activity and bioavailability of tea and tea polyphenols. Mutat. Res. 2003, 523, 201-208. [CrossRef]

141. Yang, C.S.; Lambert, J.D.; Ju, J.; Lu, G.; Sang, S. Tea and cancer prevention: Molecular mechanisms and human relevance. Toxicol. Appl. Pharmacol. 2007, 224, 265-273. [CrossRef]

142. Mukhtar, H.; Ahmad, N. Tea polyphenols: Prevention of cancer and optimizing health. Am. J. Clin. Nutr. 2000, 71, 1698S-1702S. [CrossRef]

143. Yang, C.S.; Maliakal, P.; Meng, X. Inhibition of carcinogenesis by tea. Annu. Rev. Pharmacol. Toxicol. 2002, 42, 25-54. [CrossRef]

144. Tang, S.N.; Singh, C.; Nall, D.; Meeker, D.; Shankar, S.; Srivastava, R.K. The dietary bioflavonoid quercetin synergizes with epigallocathechin gallate (egcg) to inhibit prostate cancer stem cell characteristics, invasion, migration and epithelial-mesenchymal transition. J. Mol. Signal. 2010, 5, 14. [CrossRef]

145. Adhami, V.M.; Ahmad, N.; Mukhtar, H. Molecular targets for green tea in prostate cancer prevention. J. Nutr. 2003, 133, 2417S-2424S. [CrossRef] [PubMed]

146. Chung, L.Y.; Cheung, T.C.; Kong, S.K.; Fung, K.P.; Choy, Y.M.; Chan, Z.Y.; Kwok, T.T. Induction of apoptosis by green tea catechins in human prostate cancer du145 cells. Life Sci. 2001, 68, 1207-1214. [CrossRef]

147. Amin, A.R.; Khuri, F.R.; Chen, Z.G.; Shin, D.M. Synergistic growth inhibition of squamous cell carcinoma of the head and neck by erlotinib and epigallocatechin-3-gallate: The role of p53-dependent inhibition of nuclear factor-kappab. Cancer Prev. Res. 2009, 2, 538-545. [CrossRef] [PubMed]

148. Shankar, S.; Ganapathy, S.; Hingorani, S.R.; Srivastava, R.K. Egcg inhibits growth, invasion, angiogenesis and metastasis of pancreatic cancer. Front. Biosci. 2008, 13, 440-452. [CrossRef]

149. Shankar, S.; Ganapathy, S.; Srivastava, R.K. Green tea polyphenols: Biology and therapeutic implications in cancer. Front. Biosci. 2007, 12, 4881-4899. [CrossRef]

150. Lin, H.Y.; Hou, S.C.; Chen, S.C.; Kao, M.C.; Yu, C.C.; Funayama, S.; Ho, C.T.; Way, T.D. (-)-Epigallocatechin gallate induces fas/cd95-mediated apoptosis through inhibiting constitutive and il-6-induced jak/stat3 signaling in head and neck squamous cell carcinoma cells. J. Agric. Food Chem. 2012, 60, 2480-2489. [CrossRef]

151. Zhao, J.; Blayney, A.; Liu, X.; Gandy, L.; Jin, W.; Yan, L.; Ha, J.H.; Canning, A.J.; Connelly, M.; Yang, C.; et al. Egcg binds intrinsically disordered n-terminal domain of p53 and disrupts p53-mdm2 interaction. Nat. Commun. 2021, 12, 986. [CrossRef]

152. Lee, H.G.; Choi, Y.; Kim, S.Y.; Kim, I.; Kim, Y.K.; Kim, Y.S.; Lee, H.S.; Kim, S.J.; Kim, J.A.; Park, B.B.; et al. R-CHOP chemoimmunotherapy followed by autologous transplantation for the treatment of diffuse large B-cell lymphoma. Blood. Res. 2014, 49, 107-114. [CrossRef]

153. Manero, F.; Gautier, F.; Gallenne, T.; Cauquil, N.; Gree, D.; Cartron, P.F.; Geneste, O.; Gree, R.; Vallette, F.M.; Juin, P. The small organic compound ha14-1 prevents BCL-2 interaction with bax to sensitize malignant glioma cells to induction of cell death. Cancer Res. 2006, 66, 2757-2764. [CrossRef]

154. Tian, D.; Das, S.G.; Doshi, J.M.; Peng, J.; Lin, J.; Xing, C. Sha 14-1, a stable and ros-free antagonist against anti-apoptotic BCL-2 proteins, bypasses drug resistances and synergizes cancer therapies in human leukemia cell. Cancer Lett. 2008, 259, 198-208. [CrossRef]

155. Campas, C.; Cosialls, A.M.; Barragan, M.; Iglesias-Serret, D.; Santidrian, A.F.; Coll-Mulet, L.; de Frias, M.; Domingo, A.; Pons, G.; Gil, J. Bcl-2 inhibitors induce apoptosis in chronic lymphocytic leukemia cells. Exp. Hematol. 2006, 34, 1663-1669. [CrossRef]

156. Skommer, J.; Wlodkowic, D.; Matto, M.; Eray, M.; Pelkonen, J. Ha14-1, a small molecule BCL-2 antagonist, induces apoptosis and modulates action of selected anticancer drugs in follicular lymphoma b cells. Leuk. Res. 2006, 30, 322-331. [CrossRef] [PubMed]

157. Doshi, J.M.; Tian, D.; Xing, C. Ethyl-2-amino-6-bromo-4-(1-cyano-2-ethoxy-2-oxoethyl)-4h- chromene-3-carboxylate (ha 14-1), a prototype small-molecule antagonist against anti-apoptotic BCL-2 proteins, decomposes to generate reactive oxygen species that induce apoptosis. Mol. Pharm. 2007, 4, 919-928. [CrossRef] [PubMed]

158. Dai, Y.; Grant, S. Targeting multiple arms of the apoptotic regulatory machinery. Cancer Res. 2007, 67, $2908-2911$. [CrossRef] [PubMed] 
159. Oltersdorf, T.; Elmore, S.W.; Shoemaker, A.R.; Armstrong, R.C.; Augeri, D.J.; Belli, B.A.; Bruncko, M.; Deckwerth, T.L.; Dinges, J.; Hajduk, P.J.; et al. An inhibitor of BCL-2 family proteins induces regression of solid tumours. Nature 2005, 435, 677-681. [CrossRef] [PubMed]

160. Zhang, H.; Zhong, X.; Zhang, X.; Shang, D.; Zhou, Y.I.; Zhang, C. Enhanced anticancer effect of abt-737 in combination with naringenin on gastric cancer cells. Exp. Ther. Med. 2016, 11, 669-673. [CrossRef]

161. Li, Y.L.; Sun, J.; Hu, X.; Pan, Y.N.; Yan, W.; Li, Q.Y.; Wang, F.; Lin, N.M.; Zhang, C. Epothilone b induces apoptosis and enhances apoptotic effects of abt-737 on human cancer cells via pi3k/akt/mtor pathway. J. Cancer Res. Clin. Oncol. 2016, 142, 2281-2289. [CrossRef]

162. Vogler, M.; Furdas, S.D.; Jung, M.; Kuwana, T.; Dyer, M.J.; Cohen, G.M. Diminished sensitivity of chronic lymphocytic leukemia cells to abt-737 and abt-263 due to albumin binding in blood. Clin. Cancer Res. 2010, 16, 4217-4225. [CrossRef]

163. Gandhi, L.; Camidge, D.R.; Ribeiro de Oliveira, M.; Bonomi, P.; Gandara, D.; Khaira, D.; Hann, C.L.; McKeegan, E.M.; Litvinovich, E.; Hemken, P.M.; et al. Phase I study of navitoclax (abt-263), a novel BCL-2 family inhibitor, in patients with small-cell lung cancer and other solid tumors. J. Clin. Oncol. 2011, 29, 909-916. [CrossRef]

164. Rudin, C.M.; Hann, C.L.; Garon, E.B.; Ribeiro de Oliveira, M.; Bonomi, P.D.; Camidge, D.R.; Chu, Q.; Giaccone, G.; Khaira, D.; Ramalingam, S.S.; et al. Phase II study of single-agent navitoclax (abt-263) and biomarker correlates in patients with relapsed small cell lung cancer. Clin. Cancer Res. 2012, 18, 3163-3169. [CrossRef] [PubMed]

165. Roberts, A.W.; Advani, R.H.; Kahl, B.S.; Persky, D.; Sweetenham, J.W.; Carney, D.A.; Yang, J.; Busman, T.B.; Enschede, S.H.; Humerickhouse, R.A.; et al. Phase 1 study of the safety, pharmacokinetics, and antitumour activity of the BCL2 inhibitor navitoclax in combination with rituximab in patients with relapsed or refractory cd20+ lymphoid malignancies. Br. J. Haematol. 2015, 170, 669-678. [CrossRef] [PubMed]

166. Mason, K.D.; Carpinelli, M.R.; Fletcher, J.I.; Collinge, J.E.; Hilton, A.A.; Ellis, S.; Kelly, P.N.; Ekert, P.G.; Metcalf, D.; Roberts, A.W. Programmed anuclear cell death delimits platelet life span. Cell 2007, 128, 1173-1186. [CrossRef] [PubMed]

167. Vogler, M.; Hamali, H.A.; Sun, X.-M.; Bampton, E.T.W.; Dinsdale, D.; Snowden, R.T.; Dyer, M.J.S.; Goodall, A.H.; Cohen, G.M. $\mathrm{Bcl} 2$ /BCL-xl inhibition induces apoptosis, disrupts cellular calcium homeostasis, and prevents platelet activation. Blood J. Am. Soc. Hematol. 2011, 117, 7145-7154. [CrossRef]

168. Schoenwaelder, S.M.; Yuan, Y.; Josefsson, E.C.; White, M.J.; Yao, Y.; Mason, K.D.; O’Reilly, L.A.; Henley, K.J.; Ono, A.; Hsiao, S. Two distinct pathways regulate platelet phosphatidylserine exposure and procoagulant function. Blood J. Am. Soc. Hematol. 2009, 114, 663-666. [CrossRef]

169. Zhang, H.; Nimmer, P.M.; Tahir, S.K.; Chen, J.; Fryer, R.M.; Hahn, K.R.; Iciek, L.A.; Morgan, S.J.; Nasarre, M.C.; Nelson, R.; et al. Bcl-2 family proteins are essential for platelet survival. Cell Death Differ. 2007, 14, 943-951. [CrossRef]

170. Cang, S.; Iragavarapu, C.; Savooji, J.; Song, Y.; Liu, D. Abt-199 (venetoclax) and BCL-2 inhibitors in clinical development. J. Hematol. Oncol. 2015, 8, 129. [CrossRef] [PubMed]

171. Souers, A.J.; Leverson, J.D.; Boghaert, E.R.; Ackler, S.L.; Catron, N.D.; Chen, J.; Dayton, B.D.; Ding, H.; Enschede, S.H.; Fairbrother, W.J.; et al. Abt-199, a potent and selective BCL-2 inhibitor, achieves anti-tumor activity while sparing platelets. Nat. Med. 2013, 19, 202-208. [CrossRef] [PubMed]

172. Peirs, S.; Matthijssens, F.; Goossens, S.; Van de Walle, I.; Ruggero, K.; de Bock, C.E.; Degryse, S.; Cante-Barrett, K.; Briot, D.; Clappier, E.; et al. Abt-199 mediated inhibition of BCL-2 as a novel therapeutic strategy in t-cell acute lymphoblastic leukemia. Blood 2014, 124, 3738-3747. [CrossRef]

173. DiNardo, C.D.; Pratz, K.; Pullarkat, V.; Jonas, B.A.; Arellano, M.; Becker, P.S.; Frankfurt, O.; Konopleva, M.; Wei, A.H.; Kantarjian, H.M.; et al. Venetoclax combined with decitabine or azacitidine in treatment-naive, elderly patients with acute myeloid leukemia. Blood 2019, 133, 7-17. [CrossRef] [PubMed]

174. Klanova, M.; Andera, L.; Soukup, J.; Jan, B.; Svadlenka, J.; Benesova, S.; Prukova, D.; Vejmelkova, D.; Jaksa, R.; Helman, K. Mcl1 Targeting Agent Homoharringtonine Exerts Strong Cytotoxicity towards Diffuse Large B-Cell Lymphoma (dlBCL) Cells and Synergizes with BCL2 Targeting Agent abt199 in Eliminating BCL2-Positive dlBCL Cells; American Society of Hematology: Washington, DC, USA, 2014.

175. Davids, M.S.; Roberts, A.W.; Seymour, J.F.; Pagel, J.M.; Kahl, B.S.; Wierda, W.G.; Puvvada, S.; Kipps, T.J.; Anderson, M.A.; Salem, A.H. Phase I first-in-human study of venetoclax in patients with relapsed or refractory non-hodgkin lymphoma. J. Clin. Oncol. 2017, 35, 826. [CrossRef]

176. Wang, G.; Nikolovska-Coleska, Z.; Yang, C.Y.; Wang, R.; Tang, G.; Guo, J.; Shangary, S.; Qiu, S.; Gao, W.; Yang, D.; et al. Structure-based design of potent small-molecule inhibitors of anti-apoptotic BCL-2 proteins. J. Med. Chem. 2006, 49, 6139-6142. [CrossRef] [PubMed]

177. Zeitlin, B.D.; Joo, E.; Dong, Z.; Warner, K.; Wang, G.; Nikolovska-Coleska, Z.; Wang, S.; Nor, J.E. Anti-angiogenic effect of tw37, a small-molecule inhibitor of BCL-2. Cancer Res. 2006, 66, 8698-8706. [CrossRef]

178. Wang, Z.; Azmi, A.S.; Ahmad, A.; Banerjee, S.; Wang, S.; Sarkar, F.H.; Mohammad, R.M. Tw-37, a small-molecule inhibitor of BCL-2, inhibits cell growth and induces apoptosis in pancreatic cancer: Involvement of notch-1 signaling pathway. Cancer Res. 2009, 69, 2757-2765. [CrossRef] [PubMed]

179. Azmi, A.S.; Wang, Z.; Burikhanov, R.; Rangnekar, V.M.; Wang, G.; Chen, J.; Wang, S.; Sarkar, F.H.; Mohammad, R.M. Critical role of prostate apoptosis response-4 in determining the sensitivity of pancreatic cancer cells to small-molecule inhibitor-induced apoptosis. Mol. Cancer Ther. 2008, 7, 2884-2893. [CrossRef] [PubMed] 
180. D'Aguanno, S.; del Bufalo, D. Inhibition of anti-apoptotic BCL-2 proteins in pre-clinical and clinical studies: Current overview in cancer. Cells 2020, 9, 1287. [CrossRef] [PubMed]

181. Suryani, S.; Carol, H.; Chonghaile, T.N.; Frismantas, V.; Sarmah, C.; High, L.; Bornhauser, B.; Cowley, M.J.; Szymanska, B.; Evans, K. Cell and molecular determinants of in vivo efficacy of the BH3 mimetic abt-263 against pediatric acute lymphoblastic leukemia xenografts. Clin. Cancer Res. 2014, 20, 4520-4531. [CrossRef]

182. Sengupta, P.; Chattopadhyay, S.; Chatterjee, S. G-quadruplex surveillance in BCL-2 gene: A promising therapeutic intervention in cancer treatment. Drug Discov. Today 2017, 22, 1165-1186. [CrossRef]

183. Van Delft, M.F.; Wei, A.H.; Mason, K.D.; Vandenberg, C.J.; Chen, L.; Czabotar, P.E.; Willis, S.N.; Scott, C.L.; Day, C.L.; Cory, S.; et al. The BH3 mimetic abt-737 targets selective BCL-2 proteins and efficiently induces apoptosis via bak/bax if mcl-1 is neutralized. Cancer Cell 2006, 10, 389-399. [CrossRef]

184. Vogler, M.; Butterworth, M.; Majid, A.; Walewska, R.J.; Sun, X.M.; Dyer, M.J.; Cohen, G.M. Concurrent up-regulation of BCL-xl and BCL2a1 induces approximately 1000-fold resistance to abt-737 in chronic lymphocytic leukemia. Blood 2009, 113, 4403-4413. [CrossRef]

185. Soderquist, R.S.; Danilov, A.V.; Eastman, A. Gossypol increases expression of the pro-apoptotic BH3-only protein noxa through a novel mechanism involving phospholipase a2, cytoplasmic calcium, and endoplasmic reticulum stress. J. Biol. Chem. 2014, 289, 16190-16199. [CrossRef]

186. Soderquist, R.; Bates, D.J.; Danilov, A.V.; Eastman, A. Gossypol overcomes stroma-mediated resistance to the BCL2 inhibitor abt-737 in chronic lymphocytic leukemia cells ex vivo. Leukemia 2013, 27, 2262-2264. [CrossRef] [PubMed]

187. Kapoor, I.; Bodo, J.; Hill, B.T.; Hsi, E.D.; Almasan, A. Targeting BCL-2 in b-cell malignancies and overcoming therapeutic resistance. Cell Death Dis. 2020, 11, 941. [CrossRef] [PubMed]

188. Tahir, S.K.; Smith, M.L.; Hessler, P.; Rapp, L.R.; Idler, K.B.; Park, C.H.; Leverson, J.D.; Lam, L.T. Potential mechanisms of resistance to venetoclax and strategies to circumvent it. BMC Cancer 2017, 17, 399. [CrossRef] [PubMed]

189. Fresquet, V.; Rieger, M.; Carolis, C.; Garcia-Barchino, M.J.; Martinez-Climent, J.A. Acquired mutations in BCL2 family proteins conferring resistance to the BH3 mimetic abt-199 in lymphoma. Blood 2014, 123, 4111-4119. [CrossRef] [PubMed]

190. Soderquist, R.S.; Eastman, A. Bcl2 inhibitors as anticancer drugs: A plethora of misleading BH3 mimetics. Mol. Cancer Ther. 2016, 15, 2011-2017. [CrossRef]

191. Oh, S.Y.; Kim, W.S.; Kim, J.S.; Chae, Y.S.; Lee, G.W.; Eom, H.S.; Ryoo, H.M.; Lee, S.; Kim, S.J.; Yoon, D.H.; et al. A phase II study of oxaliplatin and prednisone for patients with relapsed or refractory marginal zone lymphoma: Consortium for Improving Survival of Lymphoma trial. Leuk. Lymphoma 2016, 57, 1406-1412. [CrossRef] [PubMed]

192. Oh, S.Y.; Kim, W.S.; Kim, J.S.; Kim, S.J.; Yoon, D.H.; Yang, D.H.; Lee, W.S.; Kim, H.J.; Yhim, H.Y.; Jeong, S.H.; et al. Phase II study of R-CVP followed by rituximab maintenance therapy for patients with advanced marginal zone lymphoma: Consortium for improving survival of lymphoma (CISL) study. Cancer Commun. 2019, 39, 58. [CrossRef] [PubMed]

193. Oh, Y.S.; Lee, Y.J.; Park, K.; Choi, H.H.; Yoo, S.; Jun, H.S. Treatment with glucokinase activator, YH-GKA, increases cell proliferation and decreases glucotoxic apoptosis in INS-1 cells. Eur. J. Pharm. Sci. 2014, 51, 137-145. [CrossRef] [PubMed]

194. Oh, Y.S.; Seo, E.; Park, K.; Jun, H.S. Compound 19e, a Novel Glucokinase Activator, Protects against Cytokine-Induced Beta-Cell Apoptosis in INS-1 Cells. Front. Pharmacol. 2017, 8, 169. [CrossRef]

195. Park, C.S.; Jang, H.J.; Lee, J.H.; Oh, M.Y.; Kim, H.J. Tetrahydrocurcumin Ameliorates Tacrolimus-Induced Nephrotoxicity Via Inhibiting Apoptosis. Transplant. Proc. 2018, 50, 2854-2859. [CrossRef] [PubMed]

196. Park, H.; Chung, J.W.; Kim, A.J.; Park, S.Y.; Rim, M.Y.; Jang, Y.R.; Lee, J.H.; Park, S. A case of rectal mucosa-associated lymphoid tissue lymphoma diagnosed by endoscopic unroofing technique. Korean J. Gastroenterol. 2012, 59, 428-432. [CrossRef] [PubMed]

197. Park, M.J.; Park, S.H.; Park, P.W.; Seo, Y.H.; Kim, K.H.; Seo, J.Y.; Jeong, J.H.; Kim, M.J.; Ahn, J.Y.; Hong, J. Prognostic impact of concordant and discordant bone marrow involvement and cell-of-origin in Korean patients with diffuse large B-cell lymphoma treated with R-CHOP. J. Clin. Pathol. 2015, 68, 733-738. [CrossRef]

198. Park, S.; Cho, H.Y.; Ha, S.Y.; Chung, D.H.; Kim, N.R.; An, J.S. Marginal zone B-cell lymphoma of MALT in small intestine associated with amyloidosis: A rare association. J. Korean Med. Sci. 2011, 26, 686-689. [CrossRef]

199. Park, S.; Kim, K.M.; Kim, J.J.; Lee, J.H.; Rhee, J.C.; Ko, Y.H. Methylation of p16INK4A and mitotic arrest defective protein 2 (MAD2) genes in gastric marginal-zone B-cell lymphomas. Acta Haematol. 2008, 120, 217-224. [CrossRef]

200. Seo, J.Y.; Hong, J.; Chun, K.; Jeong, J.; Cho, H.; Kim, K.H.; Park, J.; Ahn, J.Y.; Park, P.W.; Lee, J.H. Prognostic significance of PCR-based molecular staging in patients with diffuse large B-cell lymphoma treated with R-CHOP immunochemotherapy. Leuk. Lymphoma 2017, 58, 357-365. [CrossRef]

201. Son, E.S.; Kim, S.H.; Kim, Y.O.; Lee, Y.E.; Kyung, S.Y.; Jeong, S.H.; Kim, Y.J.; Park, J.W. Coix lacryma-jobi var. ma-yuen Stapf sprout extract induces cell cycle arrest and apoptosis in human cervical carcinoma cells. BMC Complement. Altern. Med. 2019, 19, 312. [CrossRef] 